Citation as follows:

Pasternak, D., Caughlan, S., Hallman, H., Renzi, L. \& Rush, L. (in press). Teaching English Language Arts Methods in the United States: A Review of the Research. Review of Education.

Teaching English Language Arts Methods in the United States: A Review of the Research 


\begin{abstract}
What is the state of the English education methods course in the $21^{\text {st }}$ century? Summarizing the research in English teacher education since the last major study (Smagorinsky \& Whiting, 1995) of how English teachers are prepared, the authors review the state of the profession to examine trends in the field since the recent revision of the NCTE guidelines for teacher preparation, the redefinition of what constitutes methods coursework in and across programs, the rising numbers of culturally and linguistically diverse learners, the demands of assessment and accountability, and the integration of the field experience with content. The authors review research related to teaching reading strategies, integrating fieldwork with English education coursework, addressing standards in planning and teaching, meeting the needs of English language learners, and teaching with and about technology to determine how English teacher education is adapting to the demands of educating English teachers in the $21^{\text {st }}$ century.
\end{abstract}

Keywords: English teacher education, $21^{\text {st }}$ century skills, English language arts methods 


\section{Teaching English Language Arts Methods in the United States: A Review of the Research}

In 2005, members of the National Council of Teachers of English's Conference on English Education (NCTE CEE) met at a special summit in Atlanta to explore the broad questions that affect English Education and raised the question, "What is English Education?" Members of a study group at the conference determined that the field of English education "encompasses three dimensions: (1) the teaching and learning of English, broadly and inclusively defined; (2) the preparation and continuing professional support of teachers of English at all levels of education; and (3) systematic inquiry into the teaching and learning of English" (CEE, 2008a, para 1). The summit attendees stressed that central to the task of teaching English is the education and support of English instructors who, in turn, will assist their own students "to be creative, literate individuals; contributors to the cultural, social, and economic health of their communities; and fully participating and critically aware citizens of our democracy in a complex, diverse, and increasingly globalized world" (CEE, 2008a, para. 2). Exemplifying these dimensions with a set of core values clarified in their position statement (CEE, 2008b), the summit writers underscored the importance of interweaving theory and practice to prepare students at all ages to be literate, empathic individuals.

Concurrently, another group of CEE members at the Atlanta summit raised the related question, "What do we know and believe about the roles of methods courses and field experiences in English education?" They asserted that programs exhibit a set of related professional experiences that "foster a sense of authority, a spirit of inquiry, and a belief in the possibility of change among prospective and inservice teachers as well as English educators"

(CEE, 2008b, para. 1), experiences that promote partnerships, professional communities, and an 
awareness of the contexts in which learners learn. CEE members stressed that methods course work infuses "content, pedagogy, and professionalism and provides opportunities for practice, reflection, and growth" (CEE, 2008b, Beliefs statements on coursework, para. 1) and that methods classes include the teaching of instructional practices that recognize the social and cultural contexts of all learning, the diversity of learners, and the identity shift of preservice teachers as they move from student-identity to teacher-identity.

However, in attempting to define English teacher education and the role of its methods classes, it has become clear to the authors of this review that there may not be a firm understanding of what constitutes a methods class that is defined in the studies published in English teacher education. This lack of definition may occur because many studies in English teacher education omit programmatic details that would clarify whether or not the methods being studied are in the content specific methods class or $a$ methods class that crosses programs and/or even schools and departments. Additionally, what one English teacher education program calls a methods class might actually be what another program calls a cross-disciplinary literacy class, practicum or reading clinical. Therefore, in defining English education and its methods classes, as a means of examining the state of English teacher education in the $21^{\text {st }}$ century, it becomes important to focus on research that explicitly identifies coursework for preparing secondary English teachers. For the purpose of this review, the English language arts (ELA) methods course is defined in alignment with the definition proposed by NCTE's CEE: ELA methods focus on the representation and teaching of ELA content and involve the inquiry into the beliefs or opinions of its participants regarding concepts of ELA at the secondary and middle school levels, the planning of lessons or courses of study, and classroom management related to the subject- 
area methods. In employing this definition of methods, it becomes necessary to understand the context of a methods class and the programmatic details that affect it.

Much of the conversation regarding English teacher education and its methods comes to the discipline from a vision of what should be, not necessarily what is occurring in English teacher education. Programs and coursework develop in contextually dependent ways that are often driven by institutional, economic, social and political considerations - circumstances often out of the control of the English teacher educators who design programs. Additionally, despite what is taught in any English education program, school climate, choice of mentor teachers for field experiences, and location of school districts for internships also impacts how English teachers teach English (Bush, 2005; Gilbert, 2005; McCann, Johannessen, \& Ricca, 2005; Nieto, 2009), a situation that affects the content of the ELA methods course and can create tension between the school environment and the university. Thus, numerous contextual variables affect an English education program and how it defines its methods courses. Many of these variables are discussed in the NCTE and CEE policy and position statements about how English teachers are currently prepared. In particular, NCTE explores in its position and policy statements guidelines for addressing the saliency of reading and literacy instruction and how it affects teacher effectiveness and student learning (See NCTE, “Reading,” n.d.; NCTE, "Literacy,” n.d.), views that infuse all of the research-supported CEE positions. Additionally, the CEE positions span unique programs and their individual philosophies (CEE, 2008b), taking into account many of the variables that are out of the control of the teacher educator who designs an English education program. The CEE position statements explore the many factors that affect the content of the methods course, including the need for programs to develop greater programmatic coherence and better integration of field and coursework (CEE 2005; CEE 2008b; Dickson et al., 
2006), more comprehensive support for culturally and linguistically diverse learners in the English classroom (Boyd et al., 2006; CEE 2005), and increasing integration of technology and 21st century literacies with both English teaching and English teacher preparation (Swenson, Young, McGrail, Rozema \& Whitin, 2006). These positions align with current studies that examine the characteristics of effective teachers (Goe, Bell, \& Little, 2008) and, accordingly, become the foci for this review to determine the current state of English education. The CEE statements, however, did not have much to say about preparing teachers to address the culture of standards and assessments that they will face in classrooms; how that omission might be reflected in the research is discussed below.

The literature review that follows summarizes English education related research published in since 1995. In accordance with the content indicated in CEE position statements and an understanding of the characteristics of effective teachers (Goe, Bell \& Little, 2008), the authors of this review searched for research related to teaching reading strategies, integrating fieldwork with English education coursework, addressing content standards in planning and teaching, meeting the needs of English language learners, and teaching with and about technology to determine how English teacher educators are adapting to the demands of educating English teachers in the $21^{\text {st }}$ century. A review of the research on English language arts methods instruction published since 1995 indicates that few of the issues CEE has identified as critical for 21st-century teaching have been a focus of research in English education, with the exception of the integration of technology into English teacher preparation, which has received intense focus. Other salient issues not discussed in this paper have received occasional attention in the research on English methods instruction, such as teacher research (Fecho, Price, \& Read, 2004;

O’Donnell-Allen, 2001; Wall, 2004) or service-learning (Author 3, 2011). This is not to say that 
these other research areas are not noteworthy, but for the purpose of this study, they do not fall into the major categories aligned with the CEE position and policy statements and analyzed by the authors. The provision of a coherent review of research related to critical issues in English teacher education both situates existing research in English teacher education and urges researchers and English teacher educators to pursue inquiry relevant to the teaching of English in the 21 st century.

\section{English Teacher Education in the $20^{\text {th }}$ and $21^{\text {st }}$ Centuries}

A set of studies in English teacher education published in the 1990s provided a strong sense of how secondary English teachers taught and were taught. Applebee's 1993 study of how literature was taught in English classrooms reported which works were read in middle and secondary English classes, which pedagogical approaches were used with those works, and why teachers made the choices they did. Later in the decade, Nystrand, Gamoran, Kachur and Prendergast (1997) published the results of observations of hundreds of English and social studies lessons in the upper Midwest that substantiated the continued dominance of lecture, recitation and seatwork in English classrooms. Replicating this study nationally in 2003, Applebee, Langer, Nystrand and Gamoran confirmed similar findings.

In 1995, Smagorinsky and Whiting published the results of a national study of methods classes, which were examined through collection and analysis of methods course syllabi. This study provided a snapshot of the methods course in English language arts (ELA) in the United States during the 1992-1993 school year. This landmark project indicated that the ELA methods courses they studied occupied several forms (i.e., survey, workshop, experiential, reflective, and theoretical) and that the assessments used in those courses most frequently aligned with the course format. For example, workshop courses usually included an extended project -- such as an 
instructional unit -- that was collaborative in form. Smagorinsky and Whiting provided a categorization of the theoretical stances evident in the assigned course readings, although they noted the contradictory nature of some theories evident in those readings.

Almost two decades later, the above-referenced studies still dominate English education's understanding of how English is being taught in middle and secondary schools and how English teachers are prepared for these contexts. Since these studies, states have written and rewritten English content standards (often with very little input from English teachers and teacher educators), distributed curriculum frameworks, and established regimes of test-taking. The 2001 Elementary and Secondary Education Act (ESEA) created the collection of requirements and accountability measures known as No Child Left Behind (NCLB). The reactions to these measures by districts and individual classroom teachers have been mixed; but, quite obviously, teachers and administrators are operating under a different set of circumstances and rules than the ones under which classroom practices were studied in the 1990s.

In 2013, English teacher educators operate under a new context, as well. With the increased scrutiny given to teacher quality and effectiveness and the focus on new methods of "measuring" effectiveness using such tools as Value-Added Measures (VAM) (Kane \& Cantrell, 2010; Kane \& Staiger, 2008) attention has turned to providing evidence for the effectiveness of teacher education programs. National Council for Accreditation of Teacher Education (NCATE) accreditation, for example, requires performance assessment of a teacher candidate's impact on the learning of students in the student teaching classroom (NCATE, 2008), raising its expectations for accountability to subject-matter standards developed by national bodies, and requiring performance standards of teacher candidates. As NCATE merges with Teacher Education Accreditation Council (TEAC) to form the Council on Accreditation of Teacher 
Preparation (CAEP), the focus on accountability is not expected to abate. Doubts have been raised about VAM (Baker et al., 2010). While questioning how short-term guests (i.e., student teachers) in a classroom can have a significant impact on student achievement, teacher preparation programs are having to devise batteries of assessments to measure this and other factors. Since the studies from the 1990s were completed, both secondary English teachers and programs of English teacher education have had to confront a variety of significant changes in educational context, prompting the proposals by CEE and its members cited in the introduction.

These challenges were curricular: States developed individual K-12 standards and assessments and expected teachers to both align local curriculum and insure students score at proficient levels on new assessments. Districts varied in the extent to which they standardized instruction in their buildings, and textbook companies marketed packages guaranteed to help teachers and students "meet" state standards. More recently, pressures for "college and career readiness" (CCSSI, 2010) prompt English teachers to include more non-fiction texts in their courses, to teach reading strategies as opposed to literary analysis, and to require students to write to prompts similar to those found on essay exams. It is important to note here that the teaching of reading strategies, prior to 1995 , was mostly relegated to teachers certified to teach at the early childhood and elementary levels. Few preservice content area middle or high school teachers, English or otherwise, were taught how to teach reading outside that one rare content area reading class required by a few programs in the 1980s and 90s - there was a misguided presumption on the part of many teacher educators that all students were independent readers by the time they reached seventh grade. Curiously, the acknowledgement that reading needs to be taught in the upper grades has fallen on the backs of many English teachers (Wilson, 2011). This pressure on English teachers may well be increased by the shift in emphasis to include 
informational texts as outlined in the Common Core State Standards (CCSSI, 2010). In addition to the impetus to change literacy instruction in the upper grades, many states developed or enhanced existing teacher preparation standards for content area literacy, while university programs had to show their students had opportunities to meet these standards in order to keep their state accreditation.

These challenges were cultural: While the percentage of teachers self-identified as White and middle-class grew larger, more students of color and children of immigrants entered classrooms, even in communities with relatively little demographic diversity (Baber, 1995; Boutte, 1999; Burbank et al., 2005; Nieto, 2003; Sleeter, 2001; Villegas \& Lucas, 2002). Changes in information technology also prompted changes in textual production and consumption in private, civic and working life. Technology use in schools lagged behind that in the outside world.

These challenges were political: the new standards were accompanied by legislation (NCLB and the attendant growth of accountability measures at the secondary and university levels) that held individual schools and their teachers accountable for student performance on state measures to an extent never seen before. At the same time, there were political attacks on traditional programs of teacher certification, and ongoing attempts to link K-12 student performance to the programs that prepared their teachers. University programs co-exist with alternative and emergency certification routes that proceed on the "received wisdom" (Kennedy, 1999) that teaching is learned in the classroom, and that university preparation is at best an expensive distraction. Innovations in pedagogical preparation and the integration of field and coursework by university programs are ongoing, but these do not receive the attention from the media and policy-makers that accountability measures do. 
The newest challenges are economic: The recent economic downturn has reduced the resources available for teacher preparation, and new teachers face increased class sizes and reductions in district and building support that make the work of the induction period even more challenging. Because of the high numbers of retiring teachers and the high cost of attrition, teacher turnover appears to be a self-perpetuating spiral. Even before the current downturn, attrition among novice English teachers appeared higher than that among teachers as a whole (Scherff \& Hahs-Vaughan, 2008).

With these considerations as their background, the authors of this review ask: "What is it that English teacher educators teach in methods courses? How are teacher educators defining English studies across a discipline that remains constant in its teaching of print texts but changes with each new digital text?" The writers of this paper ask, "What does research published in the top journals in the field indicate about how English methods courses are changing in order to meet the demands of the 21 st century?"

\section{Method}

In order to answer these specific research questions, the authors reviewed research on English methods courses published since 1995 to learn about the work published since the last major survey of the content, theoretical orientation and pedagogical approaches to secondary English courses (Smagorinsky \& Whiting, 1995).

\section{Literature Search}

The search was done in two phases. The authors conducted a general search for research on English education, English teacher preparation and English methods courses in the main journals publishing research on English education and teacher preparation - Research in the Teaching of English (RTE), English Education (EE), Journal of Teacher Education (JTE) and 
Teaching and Teacher Education (TATE) - to gain an overview of topics. Results from using the search terms "methods course," "English Education," and "English teacher preparation" were sorted through by reading titles and abstracts to find research articles about English Education and English methods courses. All research studies on English education, English teacher preparation, and methods courses were included, as well as studies where these topics were included as one factor influencing a particular aspect of teacher preparation or development (See Table 1).

Most of the articles generated through journal search engines were not relevant to this review. Many were not research studies, but commentary on policy issues related to English teacher preparation; NCTE commission reports; descriptions of classroom practices, teacher preparation programs, or what should be taught in a methods classes; editors' introductory essays; or reflections. Other articles referred to research on English language learners in other disciplines, referred to elementary literacy methods courses, or to instructional practices outside of the United States. The search engines also generated announcements of conferences and awards, notes, author biographies, references to the journal English Education, and journals and article titles in Works Cited sections.

The two journals published by the National Council of Teachers of English, Research in the Teaching of English (RTE) and English Education (EE), could not be sorted by year, so results were sorted by hand to find studies published after 1995. Searching the term "English education" in the journal English Education brought up 1000 items, 266 published after 1995. Of the 266 items in the list, only 26 were articles relevant to this review. 
When searching on the term "English teacher preparation" in $E E, 73$ items were accumulated, 22 of which were dated after 1995. Of these 22 items, five (5) were research studies relevant to this review.

Of the 28 articles published during this time found using the search term "methods course" in English Education, only 11 were research studies that either took place in spaces deemed methods courses or that examined a particular method.

In Research in the Teaching of English (RTE), the search term "English Education" produced 226 items, many of which were duplicates from the three other searches. Duplication resulted from RTE's Annual Annotated Bibliography of Research in the Teaching of English, which listed research studies published in journals and books published across the field of education. Of the 87 items resulting from the search "English Education" published after 1995, 6 were relevant to this review. In searching the term "English teacher preparation" in RTE, 13 items were accumulated, three (3) of which were dated after 1995 with one being the Annual Annotated Bibliography. Therefore, two items were relevant to this review. Only four articles using the term "methods course" were found in RTE during the specified period: three were studies of or in methods courses, and one was commentary.

Because the Journal of Teacher Education represents all content fields/ disciplines (i.e., English, mathematics, social studies, etc.) and grade levels with regard to the methods course, the authors conducted their search for articles by cross-listing "methods course" with "English" and "language arts." This search turned up 81 articles, only eight of which made specific reference to secondary English methods courses. The term "English education" generated a list of 40 items, 28 of which were not relevant; therefore only 12 articles relevant to this review were 
published during this period in JTE. The search on the phrase "English teacher preparation" produced one article that duplicated a result from the "English education" search.

Teaching and Teacher Education is similar in scope to JTE. The search engines available for this journal do not allow for cross-topic searches. A search for "methods course" generated a list of 196 articles after 1995, treating a range of general education and subjectspecific methods courses. Three were relevant to this review. Concurrently, because a crosstopic search was not possible, a search using the phrase "English language arts" generated a list of 48 journal articles (some of which had also appeared in the "methods course" search), producing a list of the three articles that took place in English language arts programs and/or concerned the preparation of preservice middle/secondary English teachers. When the phrase "English education" was used in the search, 29 articles were listed but only six articles were relevant to this review. The term "English teacher preparation" turned up no relevant research articles.

In all, only 25 research articles were found in the major research journals that related specifically to English methods courses. Fifty research articles were generated under the search term "English education" and eight when the phrase "English teacher preparation" was used. At this stage of the search, the authors identified the main topics addressed and compared them with the recommendations coming out of CEE position statements, and noted the paucity of articles addressing various sub-areas of concern within the teaching of English that have become particularly salient since 1995 that align with NCTE and CEE policy statements: the teaching of reading and writing skills specific to English studies, the interaction of field experiences and English methods courses, the impact of content standards and assessment practices on methods 
content and pedagogy, how methods courses address the needs of English language learners, and the integration of technology into teaching practices in methods courses.

During the second phase, the authors each took a sub-area and systematically collected articles from all of the US journals publishing research and commentary on English education: English Education, Journal of Adolescent and Adult Literacy (JAAL), Journal of Literacy Research (JLR), Contemporary Issues in Technology and Teacher Education (CITE), and Research in the Teaching of English, to search for the sub-areas of particular concern within the teaching of English that have become particularly salient since 1995. A hand search on the selected sub-areas was done of the years of note in Research in the Teaching of English, English Education, and Journal of Literacy Research. The authors also each reviewed relevant literature in research handbooks or gathered from the reference sections of the few articles in a particular area where the research journals did not provide a sufficient account of research in an area. See Table 2 for an overview.

\section{Analysis}

Each author read all studies found in her sub-area, except for the search on integrating technology. Because of the large number of related articles, that author read all abstracts and conclusions in order to establish categories, and then read all the articles that mentioned a connection to the "methods course" to discern the major themes and findings. The remaining authors read each article and took notes on major themes and findings on the research in their areas in order to represent trends in their areas.

\section{Limitations}

Although the authors looked across English education and English teacher preparation to identify the research being conducted across the discipline, the authors focused their search to 
research conducted in and on methods classes, because the methods class has long been considered a major locus for subject-specific preparation (e.g., the existence of a Methods Commission in CEE; the stature of the Smagorinsky \& Whiting study cited above). Although the authors reviewed all studies done that included any attention to the methods course and its impact on ELA teacher preparation, the few studies actually being done in this area raise questions about whether the methods class is still where issues in subject-matter preparation are addressed, as discussed in the conclusion.

The search was limited to the top research journals in the fields of English education and teacher preparation because the authors considered those journals the bellwethers that signal where the field is going and what is considered significant during any particular time period. However, this strategy yielded few studies in most areas, and the subsequent snowball search suffered from a lack of systematicity across the five sub-reviews.

\section{Findings}

After an overview of research on English methods instruction published in the top English education and teacher preparation journals during the period, five sections provide reviews of the topics deemed salient to 21st-century teacher education identified above.

\section{Overview of Research in English Education Methods Courses Since 1995}

The first stage of the review provided summary knowledge of what research was being conducted about the English Education methods class during this period in English Education, Research in the Teaching of English, Journal of Teacher Education, and Teaching and Teacher Education. The authors found most of the research investigated effective means of teaching specific English language arts methods, the development of English teacher identity during the preservice period, and studies of the methods course as a context or in the context of a larger 
program. However, most publications regarding preparing English teachers in general and the methods course in particular consisted of commentary, rather than research.

The journals published by NCTE, English Education (EE) and Research in the Teaching of English (RTE), contained both commentary and research on the methods class. The relevant articles examining preservice teacher education in the journal English Education looked at topics as wide ranging as teacher identity, teacher research, critical literacy practices, issues of diversity and urban education, technology teaching and learning, and teacher educator attitudes. These included Agee's (1996) examination of the relationship between cooperating teachers and teacher candidates, Angelotti, et al.'s (2001) exploration of inquiry/pre-service teacher research, Albers' (2002) investigation of standardized testing and African American teacher candidates (Albers, 2002), and Sherry and Tremmel's (2012) inquiry into the incorporation of video into preservice teachers' practices. Other studies addressed teacher quality (Dudley-Marling et al, 2006), developing pedagogical content knowledge (Smith \& Anagnostopoulos, 2008), and urban education (Kirkland, 2010).

Articles in English Education that directly addressed the methods course largely consisted of essays or discussions of what should be taught in the methods class, including practices with English language learners (de Oliveira \& Shoffner, 2009), reflection and service learning (Kaufman, 2004), literacy (McCallister, 2002), technology (Grabill \& Hicks, 2005), and diversity and social justice (Miller, 2008). The 11 research studies in EE either took place in spaces deemed methods courses or examined a particular method and included topics such as writing and writing instruction (Smagorinsky, Wilson, \& Moore, 2011; Stockinger, 2007), critical literacy teaching (Wolfe, 2010), discussion (Basmadjian, 2008), and service learning (Author 3, 2011). 
$R T E$ also focused on examining particular methods and included practices for English language learners (Gort \& Glenn, 2010) and teaching literature (Agee, 1998; Newell, Tallman, \& Letcher, 2009); however, the Agee (1998) and Newell, et al. (2009) articles also offered studies of how methods courses serve as a particular context among others in learning to teach. $R T E$ also offered commentary suggesting methods courses go into more depth in their discussions of research and its effective application (Hillocks, 2011). Some of these same articles were generated through the RTE search on the term "English Education." These six relevant studies examined preservice teachers learning methods in specific areas (teaching literature, teaching writing), challenges in teaching diverse learners (Gort \& Glenn, 2010), or the contexts in which new teachers learn to teach (e.g., Newell, Tallman \& Letcher, 2009). Other studies on English teacher preparation addressed the use of dialogical instructional practices (Author 2, 2013) and the examination of instruction tools in middle and secondary school classrooms (Newell, Gingrich, \& Johnson, 2001).

Since the Journal of Teacher Education (JTE) represents all disciplines (i.e., English, mathematics, social studies, etc.), it provides an appropriate forum to examine research related to the role of the methods course in a teacher education program, more generally. Of the eight articles on English methods courses that fit the criteria for this review, half of them discussed how methods courses are situated in teacher education programs, including two (Anagnostopoulos, Smith, \& Basmadjian, 2007; Zeichner, 2010) that presented commentary on how the methods course is situated between "two worlds" (university and field). Two others studied issues of identity development through engaging with particular tasks in the course (Allen \& Hermann-Willmarth, 2004; Burch, 1999), one addressed using video to open up the methods course context to other classrooms (Hatch \& Grossman, 2009), and the final one 
situated an exploration whether Parker Palmer's approach to connectedness could be integrated with constructivism (Gordon, 2008). When this search was expanded to include the term "English education," three more articles studied methods of teaching literacy practices, four studied field experiences and/or school/university relationships, two looked at teacher research, and one each considered technology integration, new teacher mentoring, and teacher identity.

The three studies published in Teaching and Teacher Education (TATE) that took place in English language arts programs and/or concerned the preparation of preservice middle/secondary English teachers did not focus on the relationship of the methods course to the program but on the importance of the skill. These studies looked at issues of inclusion, teacher identity, and assessment (Clark, 2010; Graham, 2005; Kooy, 2006). Of the six articles generated through the search on "English education," two were about methods of teaching literacy practices, and one each about urban education, field experiences, new teacher attrition and professional development.

Studies of how to teach methods to preservice teachers is certainly a valid topic for research on methods courses, as is the development of teacher identity. However, in looking over this initial review, the authors found it of note that little research had been done on issues of concern raised in the CEE policy statements and on many of the 21 st century influences on teacher education outlined above. In focusing their specific literature reviews on these sub-areas, the authors of this paper were able to identify trends in 21 st century skills related to English education that will affect what is taught in the methods course since the last study (Smagorinsky \& Whiting, 1995) of this content.

The sub-sections that follow present the authors' findings from this review. In the first section, the authors explore the literature on English teach preparation for reading and writing 
instruction. Next, the authors review the research on the field experience and its effect on preservice English teacher education. The authors then review the research that addresses standards and high-stakes assessment and their impact on the preparation of English teacher candidates. The next section looks at the research about the teaching and preparation of English language learners. The final section explores the integration of technology into the teaching and learning of English. Together, these sections speak to the prevalence of research on each of these topic areas in the field of English education.

\section{Research on English Teacher Education for the Teaching of Reading and Writing Skills in the ELA Methods Classroom}

Increasingly, those interested in adolescent literacy, and in content area literacy in particular, have moved to a discipline-specific literacies perspective. Moje (2008) suggested that each discipline (mathematics, science, English/language arts, etc.) has its own ways of seeing the world, its own discourses, identities, and knowledge bases, all based on human interaction within the discipline. Thus, to reconceptualize reading and writing across the curriculum as disciplinespecific literacies means that each teacher would take on the task of assisting his or her students in accessing and reconstituting the literacies of that discipline. This is a tall task, since teachers do not usually have a blend of disciplinary knowledge (an insider) with generic literacy skills (an outsider).

Wilson (2011) took up the call for discipline-specific literacies, using a social semiotics perspective to provide a sense of uses and understandings of texts in different disciplines. In English/Language Arts, she pointed out the differing traditions of what it means to "do" English, which has a corresponding impact on what a "text" is. If English class is seen as learning to write correctly, "common texts may be stand-alone sentences that students read with the 
intention of underlining and annotating words" (Wilson, 2011, p. 437). More common to ELA classes would be an understanding of English as the study of literature, in which case literature of differing genres would be the focus of the text. Multimedia and multimodal texts, such as those found online, would also be considered texts, particularly with the move toward digital technologies in schools. Approaches to texts also vary, including the development of multiple interpretations (reader response); studies of form, structure and literary techniques; in addition to a common focus on the process of reading and writing.

Wilson pointed to the reality that English teachers are held responsible for literacy in many secondary schools: “...In many schools, English language arts remains the designated province for students to learn about processes behind reading and designing a variety of texts" (Wilson, 2011, p. 437). This relegation of literacy instruction to English teachers is also pointed out by Hall (2005) and Lester (2000). The burden of responsibility on English teachers is particularly troubling if English teachers' penchant for literary texts causes them to prefer humanities-based texts over non-fiction (Hanauer, 1997). As a result of the increased movement toward discipline-specific literacies, as well as the existing reality of English teachers' perceived responsibility for literacy instruction, it is critical to examine the ways in which English teachers are taught to address reading and writing instruction, particularly through the methods courses that they take as part of their certification programs.

Literacy instruction and English teacher education. Much of the scholarship around the teaching of reading and writing skills in secondary schools focuses on preparing preservice English teachers to teach literature and to teach writing around literature, or to use some specified approach or technology to teach literature. For example, Newell, Gingrich, and Letcher (2003) explored how one early-career English teacher appropriated and used constructivist 
practices for teaching literature. In addition, the authors of this review found several studies that explored the preparation of teachers of all content areas in reading and writing instruction at the secondary level, through content area literacy courses. These studies explored the importance of teachers' backgrounds, their knowledge of reading strategies and metacognition, and the difficulties of ensuring transfer from the teacher education program to the teaching context (Akyol \& Ulusoy, 2010; Alger, 2009; Donahue, 2003; Lesley, Watson, \& Elliott , 2007; Wilson, Grisham, \& Smetana, 2009).

A series of case studies by Smagorinsky, his colleagues and their students (Johnson, Thompson, Smagorinsky, \& Fry, 2003; Smagorinsky, 1999; Smagorinsky, Lakly, \& Johnson, 2002; Smagorinsky, Rhym, \& Moore, 2013) examine how novice English teachers find their way through their first few years of teaching, how they put into practice conceptual and pedagogical tools regarding instruction in English classes, where those tools come from, and how they are instituted in practice. Although these studies note a lack of helpful instruction in English methods courses, collectively they indicate the difficulties experienced by preservice and novice teachers in developing pedagogical tools for teaching English.

The remainder of the studies reviewed here are those that focused specifically on the preparation in methods courses of English/Language Arts teachers for literacy instruction. Although a relatively small set of studies, when taken together these studies indicate that researchers are examining how conceptual foci and instructional techniques used in methods classes can result in changed teaching practices during student teaching and into the first years of professional teaching. The studies described below examined the use of dialogic reading instruction that drew on Nystrand's (1997) work in secondary English classrooms (Aukerman, Belfatti, \& Santori, 2008); of the Video-Based Response and Revision program (Author 2, 
2013); pairing of preservice teachers and middle school students to discuss young adult literature in an online setting (Groenke, 2008), teachers' uptake of writing pedagogy from their teacher education programs (Grossman, et al., 2000), the use of writers' notebooks and writing workshop (Stockinger, 2007), and fiction writing (Glenn, 2007).

Grossman and her colleagues (2000) used an activity theory approach in a longitudinal study designed to examine how teachers take up and use pedagogical tools for teaching writing, for a five-year period after their teacher education program. This study found that the most influential pedagogical tools employed during teacher education coursework were conceptual tools that were accompanied with practical strategies. A second important finding from this study was that pedagogical tools obtained through teacher education coursework were most evident during the second year of teaching. For example, an analysis of materials from the secondary English methods course indicates that students were not explicitly taught how to scaffold student writing. As a result, several of the preservice teachers in the study sought more rigidly structured materials from sources external to their teacher education programs. The packaged programs that these teachers were introduced to were eagerly adopted during their first years of teaching, and then critiqued and adapted during following years. The authors pointed out that “...perhaps what is most striking across these cases, however, is the teachers' ability to hold on to important concepts, even when they were trying out practices that were antithetical, in certain ways, to their initial conceptions" (p. 657). Of particular importance to the novice teachers was the ability to reflect on their own teaching: "Pedagogical tools developed during teacher education provided a set of frames through which to view teaching and a technical language to make sense of what teachers were experiencing” (p. 658). Implications from this study for English teacher education 
include the need to provide both conceptual and practical tools for teaching writing in methods courses.

Aukerman, Belfatti, and Santori (2008) drew on Nystrand's (1997) work in secondary classrooms on allowing student voices to direct conversational flow around texts, using grounded theory qualitative methods to examine the struggles of two graduate literacy students as they work to learn and to adopt a dialogic mode of reading instruction. The authors contrasted this style of teaching with what they call a top-down, strategy-focused perspective, and indicated that their adoption of a dialogic mode of teaching reading with elementary students allowed students to take ownership of their own reading and to adopt, more naturally, useful reading strategies.

A related project drawing on Nystrand's (1997) work on discussion as related to literacy is Groenke's (2008) case study of one preservice teacher who participated in the Web Pen Pals project, in which middle school students and preservice teachers discussed young adult literature in an online setting. One of the goals of this project was to help preservice teachers take a critical stance on literature; another was to give them practice in facilitating discussion. The findings of this study indicate that the preservice teacher, Amanda, most frequently asked questions to introduce a new topic or to solicit a defense or a line of argument. Even though the questions Amanda asked could have promoted critical analysis, students' work toward critical analysis were often interrupted by her questions introducing yet another new topic. Groenke's (2008) research indicates the difficulty of moving novice teachers into a critical stance and the complexities involved in teaching the facilitation of discussion. When taken together, these two studies indicate both potential and need for future research on the impact of instruction in dialogue and discussion as a means to improving literacy instruction in English/Language Arts classrooms. 
Studies in literacy practices not only addressed the development of habits of mind but also the need for practical tools. Stockinger (2007) carried out a self-study of her English/Language Arts methods course to examine how the writers' notebook assignment as a pedagogical tool influenced preservice teachers' understanding of how to teach writing. Stockinger used constant comparative analysis of preservice teachers' writing during both methods courses and field experiences, as well as observations of teaching experiences. This study's findings stressed the importance of addressing preservice teachers' prior beliefs about teaching writing, as well as modeling student-centered learning strategies during the methods course, in order to ensure that novice teachers can move beyond their own experiences with writing and implement effective writing instruction.

Glenn (2007) examined how asking preservice teachers to write narratives and to reflect on how their writing influences their reading practices, and she found that the preservice teachers engaged in this work experienced an increased commitment to reading and a better understanding of the texts that they read. By analyzing the preservice teachers' reflections on their writing using a constant comparative method, Glenn found that the act of writing improved the preservice teachers' reading strategies. This study, unfortunately, left unexplored the transfer of these improved reading and writing abilities to their student teaching or professional classrooms.

A recent study (Author 2, 2013) examined the use of a Video-Based Response and Revision program during a year-long methods course and the subsequent year-long internship, using a design-based research approach. The preservice teachers who participated in the project planned for dialogic instruction; this form of instruction has increasingly been connected to literacy improvement. This project gave preservice teachers both practical and conceptual tools 
dedicated to improving students' interactions in authentic discussions, and the study showed that this effort was successful in changing preservice teachers' practice and instruction.

This small set of studies, focused as they are on the conceptual and practical tools that can be introduced in methods courses to improve the pedagogy and instruction of novice teachers, is a toehold in the work that needs to be done to understand how to improve the teaching of literacy skills by novice teachers. There is some hope that combining conceptual tools with practical instructional strategies can carry over into the student teaching semester as well as the first years of teaching. Augmentation of the combination of conceptual and practical tools with reflection in the form of video is another technique that bears promise for English methods instructors.

Future research in the teaching of literacy skills and English teacher education. This review of research on instruction related to reading and writing pedagogy in the English methods course underscores the way in which research in English teacher education has focused, instead, on literary studies and on writing about literature. It appears that English teacher educators have opportunities to continue work in this area by taking into consideration a wealth of knowledge on literacy skills and comprehension instruction, from experts in content area or disciplinary literacies (e.g., Hall, 2005; Moje, 2008; Wilson, 2011). Perhaps most importantly, future research in this area should continue to enlarge our understandings of the conceptual and pedagogical tools that could be introduced in methods classes regarding the teaching of reading and writing, so as to extend the research base in this area. Drawing on data from the longitudinal approach employed by Grossman et al. (2001), new studies could broaden the base for data collection by collecting data across multiple institutions using quantitative, qualitative, and longitudinal approaches. Such intensive and extensive approaches would require following preservice 
teachers in diverse programs through their first few years of teaching. Data collection points could include course documents from the teacher education programs, initial and subsequent interviews, observations, and document collection. Additionally, researchers carrying out such a study would have to consider the background and reading/writing history of the preservice teacher, as well as the contexts in which the teachers are employed.

As Grossman, et al. (2001) indicated, the methods learned to teach English are often closely tied to student teaching placements and field experiences. The next section presents a review of research on field experiences that are integrated with English methods courses.

Research on the Influence of Field Experiences in English Methods Courses in Pedagogical Shifts in Preservice Teachers

Within teacher education, it is a common, supported, and encouraged practice for students to engage in field experiences to "learn to teach." However, how those field experiences are conceived and implemented, whom the student teachers observed or worked with, and at what point in the teacher education program field experiences occurred are often contextual to each individual English teacher education program. Field experiences throughout teacher education programs include observations, tutoring, full class teaching opportunities and vary in length of hours and context of the placement.

In Preparing Teachers for a Changing World, Darling-Hammond and Bransford (2006) explored the knowledge base for preparing teachers to teach. In a chapter entitled "The Design of Teacher Education Programs," (Hammerness et al, 2006) the authors note about clinical and field experiences that "Program designs that include more practicum experience and student teaching, integrated with coursework appear to make a difference in teachers' practices, 
confidence, and long term commitment to teaching" (411). This notion of a coherent, integrated approach to teacher education would work to combat the two-worlds pitfall found by FeimanNesmer (1989) where the student teachers worked to make sense of the theory from their teacher education program against the realities of everyday classroom struggles. However, in a day and age of budgetary cuts that impact the funding of teacher education programs placed alongside the call for increased accountability for teachers (and teacher education programs), there is a question of what the profession really knows about field experiences and how this knowledge is developed.

In a study of research on teacher education programs (not specifically secondary English programs) commissioned by the Department of Education in 2002, Wilson, Floden and FerriniMundy (2002) found that

The research on clinical experiences is weak in several ways. Much of the early research focused on cooperating and prospective teachers' attitudes. Although it is important to know how teachers feel about the benefits of field experiences, attitude surveys do not answer questions about what prospective teachers actually learn (p. 196).

In this review of research, the studies examined were small in scale, and although there were findings that would indicate the importance of field experiences in teacher education programs, it would be impossible to generalize these findings across teacher education programsField experiences and English teacher education pedagogy. A search of scholarly journals in English teacher education since 1995 would indicate that very little research is being done on the pedagogical shifts of pre-service teachers that occur when field experiences are connected to structured assignments in a specialized English methods course. There are directives on what the methods course looks like or should be (Fecho, 2003; Fleischer \& Fox, 
2002; Marshall \& Smith, 1997; Pope, 1999; Richmond \& Whyte, 2004), how methods courses are affected by the changing idea of diversity and the use of multicultural literature (Margerison, 1995; Rosen \& Abt-Perkins, 2000), and how methods courses use simulated performance (Finders \& Rose, 1999). There are studies of field experiences in diverse settings (DeStigter, 1998) and studies in building partnerships with teachers and local school districts (Cercone, 2009; Smith \& Anagnostopoulos, 2008; Zigo \& Derrico, 2009); but when it comes to the pedagogical shifts seen in preservice teachers from structured assignments in English language arts methods courses while engaging in field placements, there is very little research to be found. However, an interesting strand of research did look at the negotiations that occurred (or did not occur) during the student teaching experience between what student teachers bring from their teacher education programs, and what the pedagogies and materials they choose to use, are allowed to use, or negotiate to use during their student teaching placement. A supervisor's account is examined (Slick, 1998), as well as student teachers' accounts (Agee, 1996; Graham, 1997; Dong, 2008; Smagorinsky, Lakeley, \& Johnson 2002; Smagorinsky, Rhym, \&Moore, 2013).

Partnerships between teacher education programs and school sites provided another way to negotiate the differences between teacher education programs and school sites (Graham, 1997; Smith \& Anagnostopoulos, 2008; Fairbanks, Freedman, \& Kahn, 2000). These negotiations and partnerships provide support for student teachers' ability to bridge the divide between teacher education programs (specifically the methods courses) and the student teaching (or field) experience. Although there is no direct correlation to the methods courses, except through the partnerships discussed, these negotiations do seem to provide an opportunity or place for pedagogical shifts to occur while teaching. 
By broadening the search terms to include "English methods courses" and "field experiences" and/or "observations" and/or "clinical," there were many studies found placed within elementary certification programs or literacy practicums that examined a specific field experience that was connected to a methods course. These literacy practicums may have included preservice secondary English teachers, but they were not solely devoted to content specific methods as discussed in the introduction of this review.

Four studies were found that addressed the secondary English methods (content specific/field connection). The studies published in this area examine fundamental shifts in pedagogical knowledge during the student teaching experience and tracked the changes back to the methods course that took place the semester before student teaching or a methods course being taken concurrently. These studies explored preservice teachers' prior beliefs and goals for teaching English (Newell, Gingrich, \& Johnson, 2001), leading discussions in urban classrooms (Basmadjian, 2005), instructional scaffolding (Newell \& Connors, 2011) and planning for critical literacy (Wolfe, 2010). Findings from these studies showed that with carefully planned, supervised experiences that allow for debriefing and time to "work through" the disconnect, changes in a pre-service teacher's pedagogical content knowledge is possible.

While each of these studies took place during the student teaching or internship field experience, they did explore the learning of the methods course as well. The context of what constituted a methods course or how many hours of a field experience students engaged in before the student teaching semester was vague, as well as the actual assignments or direction students were given, but the pedagogical shifts shown were significant.

Future research in connecting methods courses and field placements. Research is being done at the elementary level that connects the methods course with the field/clinical 
experience, assignments and discussions (Carpraro, Carpraro \& Helfeldt, 2010; Garner \& Rosen, 2009; Rosen \& Gere, 1996) that secondary teacher educators might want to replicate. Although these studies are small in scale, their findings confirmed that structured connections between assignments and field placements proved to be more significant in teacher candidate learning than the actual placement of the student teacher. Debriefing also proved to be a key element for both Rosen and Gere (1996) and Garner and Rosen (2009).

Rosen and Gere (1996) took a different approach while teaching a language arts methods course by splitting their students into two groups: one at an elementary field placement and the other at a middle school placement. Students were given information about the classroom, lesson plans, and curriculum pieces before entering their placement classrooms. During the observation portion of the placement, the students observed as an entire group, visiting one classroom together, and engaging in activities with students. The group then debriefed together with the cooperating teacher so that each could reflect on the classroom experience. Structured observing and debriefing allowed the teacher candidates to experience the classroom, while also giving them access to what the teacher thought about lesson planning.

Garner and Rosen (2009) also saw debriefing as a significant step in making field experiences meaningful in their literacy methods course. The authors were part of a partnership with local schools that allowed the teachers in the schools to assist in the coordination of the assignments and field experiences. According to their findings, students made clear connections between theory and practice when they participated in assigned debriefing sessions with their cooperating teachers. Theory/practice connections were possible because the cooperating teachers in the schools moved from mentor teachers, or willing participants, to leaders in the key events of the student teaching partnership. 
Carpraro, Carpraro and Helfeldt (2010) examined the differing field experiences in an elementary certification program. Across three groups of students placed in a control group, a PDS field experience, and an inquiry-based field experience, the researchers found that the structure of activities in the field experience being connected to the concurrently taken methods course was more significant than the actual field placement. This study was larger than most as the researchers worked with selected groups from a larger pool of elementary certification students. Replicating this design would, most likely, not be an option for many secondary English programs because secondary programs do not enroll at a similar volume.

Although there is research being done on field placements in secondary English language arts programs in regards to diversity and the building of partnerships, it would appear that not a significant amount of research is taking place at the secondary level that examines preservice teachers' pedagogical shifts during a field experience due to the methods course's structure and assignments. There are several developments during teacher education programs and student teaching that help to explain the small number of studies that are conducted on pedagogical shifts during field experiences. One possible explanation is that the context of teacher education programs at the secondary level are so varied that there may not be a field experience connected directly to a content specific English methods course in teacher education programs. Another may be that methods courses are often taken concurrently with the student teaching semester at larger universities and thus the focus of the research is not directly focused on pedagogical shifts connected to methods courses. Without a clear definition of what constitutes a methods course and what is deemed a field experience (observation through student teaching), it is difficult to determine how much research is being done. Finally, there is the tension often experienced between the university classroom and some student teaching classrooms: many large teacher 
education programs place in classrooms where the pedagogical values held by mentor teachers and the school or district may be at odds with methods promoted by the teacher education program, as the culture of schools tends to perpetuate status quo pedagogies (Smagorinsky, 2010).

The tension between school culture and a teacher education program (Smagorinsky, 2010) raises larger issues. The environment of the school in which students are placed for field experiences and student teaching can affect the ability of teacher candidates to be able to use the pedagogical tools and theories they are exposed to through their studies (hence the negotiation and partnership research above). These issues can include cooperating teachers who do not release control of their classes or hold different philosophical stances. There may be tracking of students, behavioral climates in classrooms, lack of texts and resources, and general morale within the school environment that can affect the student teacher's success in a field experience. All of these issues can derail teacher candidates and teacher education programs in their pursuits to provide the teacher candidates with opportunities to learn through field experiences.

\section{Preparing ELA Teacher Candidates to Address Standards and High-stakes Assessment}

Scholarship that explored the preparation of preservice teachers in English to address K12 content standards and high-stakes testing is negligible. Researchers have studied the impact of standards and assessments on K-12 classrooms: the challenges of negotiating narrowing standards within the larger universe of English language arts curriculum (Applebee \& Langer, 2009; Ketter \& Pool, 2001); the impact of standardized tests on what is taught in K-12 classrooms (Anagnostopolous, 2003; Dooley \& Assaf, 2009; Scherff \& Piazza, 2005); the difficulties teachers face when schools and districts mandate packaged curriculum that teachers do not see as meeting students' needs (Pease-Alvarez \& Samway, 2008); the strict focus on test 
preparation and avoiding NCLB sanctions that compel teachers to narrow their curriculum to those limited goals (e.g., the English Education special issue on NCLB: Fleischer \& Fox, 2004). However, it is apparent from this review that the impact of standards and high-stakes testing on English/Language Arts methods courses is not a focus of scholarship in English teacher preparation. While it is still too early to expect published empirical studies of the impact of Race to the Top, pressures on secondary schools for not making Annual Yearly Progress (AYP) have been building for a decade, and high-stakes assessments of progress in state standards have been in place in some states (e.g., Texas, California) since before NCLB was passed. The discipline has had little to say about the following questions and how different approaches to addressing standards-based reforms might impact teaching and learning:

- Do preservice teachers study their state standards closely?

- Do preservice teachers have an opportunity to compare different standards (e.g., their state standards with those of other states or with the NCTE or INTASC standards) and discuss their affordances and limitations?

- Do they plan from the standards, or choose standards to include, that happen to align with what they are planning?

- Do preservice teachers investigate how teachers in a department or district align curriculum with state or district standards?

- Do they study the history of standards development, analyze standards for underlying assumptions and ideologies, or critique them?

The following review discusses some issues related to standards-based education that do appear in the literature, possible reasons why it is so rarely studied, as well as those few publications that do address the issue. 
Meeting standards at the university and K-12 levels. Teacher educators have their own sets of standards to meet: some of these are set by NCATE and a content-specific professional association, such as NCTE; others are created by state boards or departments of education. A search linking teacher preparation to standards most often turns up discussions of teacher educators' approach to these standards (e.g., Heller, Wood \& Shawgo, 2007). Surprisingly, these are not necessarily linked to the K-12 standards preservice teachers will be required to address.

States vary widely in their policies related to preparing teachers to teach to K-12 content standards. Sandra Stotsky, in The State of State English Standards, reported in 2005 that only about half the states at that time aligned content requirements for teacher candidates with the K12 content standards. A more recent review by Kober and Rentner (2011), addressing teacher preparation in light of the CCSS, reported that only about half of the states that responded said they planned to align teacher preparation with the content and pedagogy of CCSS, most deferring action until 2013 or later. Thus, while states, accreditation agencies, and subjectmatter organizations have developed both K-12 standards and teacher preparation standards, standards at these two levels are often not required to align. The lack of alignment might help explain why the CEE/NCATE standards from 2003 that have provided the basis for reviews of English teacher education programs over the past ten years nowhere mention preparing preservice teachers to teach to state standards, or using assessment data from standardized instruments to plan instruction. The new version of these standards, recently submitted to NCATE/CAEP (NCTE, 2012), only mention looking at the Common Core standards to make sure the NCTE standards included informational texts and argument (p. 7), but nowhere are the Common Core standards listed in the lists of resources included after each standard; in addition, standards are mentioned as one element to be taken into consideration a few times in relation to 
planning (p. 21, p. 29, p. 34) and once in relation to implementation (p. 34). In the case of English language arts education, there exists a tension between the need to prepare preservice teachers for school district expectations and professional and ethical resistance to what are seen as one-size-fits-all standards and tests that have too heavy an influence on classroom activity.

English teacher education's resistance to standards-aligned teaching. A number of scholars articulated resistance to the idea of standards as currently developed and implemented by political bodies. The assumptions underlying standards, as they are read by teacher educators, violate deeply held principles of many scholars in English teacher education. Tremmel (2010) pointed out that this resistance reflects a long-standing opposition between progressive educators and various social efficiency movements, of which the standards movement can be seen as the latest instantiation.

Parallel policies and actions by standards proponents tended to reinforce English educators' negative image of standards as a rather narrow, unitary set of goals to work towards, and/or a set of best practices that will get everyone there (Alsup et al., 2006). The tendency of large schools and districts to implement one-size-fits-all curriculum and textbooks in order to meet the standards, the establishment of the What Works Clearinghouse by the US Department of Education (DOE), and high-stakes tests that narrowed the lens even more contrast with English educators' attempts to enlarge the range of texts studied, their research exploring the effects of context on student learning, and preservice pedagogy focused addressing the needs of the a diversity of cultures and identity groups in schools through varying approaches to engaging them in academic literate behaviors (Au \& Raphael, 2000). Because standards are political documents written by committees largely composed of non-educators, standards can 
work to maintain status quo assumptions about literature and writing and may not reflect recent scholarship on literary study, writing pedagogy, and student engagement (Author 2, 2007).

Although methods instructors may wish to teach resistance to the current standards movement rather than assimilation, doing so adds to the distance between university lessons and the conditions K-12 teachers labor under at present. While it is true that teachers' students can meet standards while engaged in progressive pedagogies, simply telling novice teachers to enact such progressive pedagogies does not help them or their mentors work out how to do so or how to make the case to administrators nervous about their own fate in an increasingly constrained system. Alsup et al. (2006) suggested opening a dialogue between university teacher educators and policy-makers, while Tremmel (2010) suggested looking at the demise of the Progressive movement for lessons on how to find a middle way of operating, rather than continue to be marginalized. How such suggestions are applied to teaching novice teachers how to deal with the realities of state and federal standards policies remains understudied.

\section{Preparing English teacher candidates for standards-based curriculum. Only one} source linked empirical data regarding preparing teachers to teach a standards-based curriculum with success in teaching. Boyd, Grossman, Lankford, Loeb and Wyckoff (2009) focused on differences among K-8 teacher preparation programs serving New York City. A minority of these programs provided opportunities to review the NYC standards and curriculum in math or ELA, but where they did, Boyd et al. found a correlation with student achievement in the first year of teaching. This correlation was part of a larger finding that hands-on experiences similar to those students would face in their first year did correlate with higher student gains.

\section{Advocating for providing preservice teachers with an understanding of policy.}

Several articles in professional journals included the expressed need to prepare preservice 
teachers for the realities of standards, tests, and constrained curriculum. However, it has not been the focus of scholarship, and rarely includes descriptions of how to best prepare teachers for these particular realities. For example, Scherff and Hahs-Vaughan (2008), in their study of teacher retention and reasons for leaving the profession, suggested preservice teachers be alerted to current conditions related to poor teacher retention. They found evidence in national databases that an important factor is a lack of control over working conditions linked to pressures to raise test scores for teachers of mathematics and English language arts. English teachers leave the profession at a proportionately higher rate than teachers in general (Scherff \& HahsVaughan, 2008). Some of Smagorinsky's work has also addressed the disjunction between ideal pedagogies taught in university settings, and the realities of constrained curricula and test preparation in schools (Dickson \& Smagorinsky, 2006; Smagorinsky, Lakly \& Johnson, 2002), realities based in long-standing cultures of schooling grounded in traditional schooling practices (Smagorinsky, 2010). In particular, Smagorinsky studied one particular program that has worked to build long-term, stable relationships between the university and teachers in the schools, who help in the design of the preservice experience (e.g., Smagorinsky, Jakubiak, \& Moore, 2008; Smagorinsky, Lakly, \& Johnson, 2002). McCracken (2004) also suggested addressing policy issues in methods courses, helping to develop a critical view that is informed by research. She urged teaching beginning teachers to conduct their own classroom research, based on sound scientific principles, in order to become "artists and scientists," ready to resist pressures to teach in ways they feel are harmful to their pupils.

Directions for future research. English teacher education needs more studies like that carried out by Boyd and colleagues (2009), as well as studies of teacher preparation programs' 
effectiveness in promoting teaching practices that have been shown to engage students in challenging academic tasks that relate to real-world uses of the language arts.

The standards as written in most states and in the CCSS can be considered the floor, not the ceiling, of student achievement. In addressing the standards in methods classes, instructors can prepare students to "meet and exceed" the standards (Beach, Thein, \& Webb, 2012), while maintaining the traditions of ELA that promote the authentic and productive uses of language in the roles of reader and writer, citizen, student, worker, and well-rounded human being for all learners.

Another direction for research that could inform preservice teaching in this area is represented by Frederickson's (2011) study of how elementary teachers used standards as one resource among many in planning and implementing instruction - a study that would be worthwhile to replicate at the secondary level. English education would benefit from more research on how teachers actually use policies and standards, in order to teach preservice teachers to approach them as tools to support their work, rather than constraints to resist.

\section{Learning to Teach English Language Learners in the ELA Methods Course}

Preparing preservice English teachers to meet the needs of diverse students in the classroom includes addressing the needs of English Language Learners (ELLs) in middle and secondary schools. CEE recognized that the needs of ELLs differ from the needs of other learners and has supported the creation of guidelines for preparing English language arts teachers in this area (NCTE 2006/ CEE 2005). While there is recent research being done about and with ELL students in the context of teacher education programs, more generally (e.g., de Oliveira \& Athanases, 2007; Lucas, Villegas \& Freedman-Gonzalez, 2008), within the context of the English methods, the topic of teaching ELLs has received little research attention. Evidence of 
responding to the critical question of "what should preservice English teachers know about the teaching of English language learners?" appears to be only emerging within the context of teaching English, and instead consistently aligned with guidelines about preservice teachers' knowledge apart from their disciplinary teaching field. Below, three strands of this topic are highlighted with regard to the preparation that English language arts teachers receive in learning to teach English language learners: empirical studies of how English teachers are prepared to teach ELLs, studies of culturally-responsive teaching, and preservice teachers' understanding of the changing roles of English teachers. These three areas emerge from empirical work and commentary in English education that has addressed the teaching of English Language Learners as it is related to learning to teach English.

\section{Research on preparing English teachers to teach English language learners. CEE's}

position statement (2005) on supporting linguistically and culturally diverse learners in English Education laid a solid foundation for encouraging English educators to become familiar with work in both multicultural education and bilingual/ bicultural education. The document articulated beliefs on issues such as funds of knowledge (Moll, Amanti, Neff, \& Gonzalez, 1992), language diversity (Perry \& Delpit, 1998; Smitherman, 1999), culturally relevant pedagogy (Ladson-Billings, 1994), and critical orientations toward diversity (Morrell, 2004; Villanueva, 1993). Research on English language learners has been an area of growing attention in the past decade (see Fisher, Rothenberg, \& Frey, 2007; Portes \& Smagorinsky, 2010), especially as this research relates to the growing population of US school aged children whose native language is not English. By the year 2030, it is estimated that over $40 \%$ of the K-12 population in U.S. schools will be children whose first language is not English (U.S. Census Bureau, 2010). 
As Boyd et al. (2006) noted, “in today's increasingly diverse society and communicative contexts ... English language arts teachers face even more complex challenges than the simple education of learners about the realities of language: they are simultaneously charged to teach all English speakers regardless of dialect and all second language users and learners, regardless of their early language experiences" (p. 9). Yet, how does a teacher of English language arts develop such competencies?

In Research in the Teaching of English, the topic of teaching ELLs is addressed in 15 research articles since 1995; 14 of these articles have been published since 2000. While most of these articles are empirical studies of English language learners themselves (e.g., Rymes, 2003) or studies that utilize particular strategies approaches to teach ELLs (e.g., Olson \& Land, 2007), most do not explicitly address learning to teach English language learners. Gort and Glenn's (2010) self-study of addressing the teaching of ELLs in an English methods course stood as an exemplar in English Education for considering how to prepare English teachers to teach ELLs. In this self-study, Gort and Glenn, both the researchers and teacher educators, worked together to implement curriculum for beginning English teachers in the context of an English methods course that would challenge their notion of how to respond to a changing demographic in U.S. classrooms. The study reported on how Glenn was able to reorganize her methods course to address myths concerning ELLs; incorporate texts that were written by silenced authors; implement activities that focus on addressing misconceptions about working with ELLs.

Other studies of field experiences in English education (e.g., Author 3, 2011) use the "field" or the context of a service learning experience to discuss the teaching of ELLs. This serves two purposes: uniting the theories studied about ELLs in the methods course with the practice of tutoring/ teaching ELLs in schools or community-based sites. Yet, this begs a critical 
question that Gort and Glenn (2010) continually raised throughout their study: is English content "replaced" by ELL-oriented content if the latter is included in the English methods course? As Glenn noted, "how does one go about determining what's worth keeping and what might be sacrificed to ensure inclusion of this new EL content?" (p. 68). The authors stated that infusion of such content does not necessarily "replace" existing content; rather, it reorients the methods course to address new, relevant issues in the teaching of English language arts. Yet, the findings of Gort and Glenn's study rested heavily on Glenn's (an English educator) feelings of inadequacy in infusing ELL-related content into the methods course. As the authors note, "this recognition of inadequacy was not resolved (and remains unresolved to date)" (p. 77). The authors also noted that, while the infusion of ELL-related issues into the methods course "raised students' awareness of EL issues and provided them with classroom strategies, it would have been impossible for [Glenn] to include attention to all topics related to teaching ELs within a single course" (p. 77). Finally, it should be noted that the authors elaborate on how Glenn, an English educator, "was not yet versed in the cognitive components of EL instruction (e.g., language acquisition processes, role of language in learning, development of academic vs. social language)" (p. 78), and the inclusion of this would entail much risk for an English educator and would perhaps expose a lack of knowledge on the part of the English educator.

This final point raises a critical question in the field of English education as it urges the field to consider how to integrate research from the areas of bilingual/ bicultural education into the teaching of English. What knowledge is most crucial for beginning English teachers as they embark on teaching in classrooms populated with linguistically diverse students and how should teacher educators determine what knowledge is of most worth? 
Aside from Gort and Glenn's (2010) self-study of revisions to the methods course to address the teaching of ELLs, few other studies exist that explicitly link the English methods course to the field of bilingual/ bicultural education. In the past seventeen years, the Journal of Adolescent and Adult Literacy has provided excellent case studies of ELL learner profiles (Black, 2009; Cohen, 2007), ELL identity and reading/ writing achievement (Fernsten, 2008), and articles that discuss barriers to English language learners' achievement in the area of reading, more generally (see Grant \& Wong, 2003). The Journal of Adolescent and Adult Literacy has presented itself as a cross-disciplinary forum for the fields of English education, literacy education and reading education to learn from one another. Grant and Wong's (2003) article cited teacher education programs and the field of literacy education, most broadly defined, as a major force in upholding barriers that have prevented change in teacher training in order to meet the needs of ELLs.

Though content fields, such as English language arts, have been encouraged to address the teaching of English language learners, Moore, Bean, Birdyshaw, and Rycik (1999) asserted that few middle and secondary programs are currently preparing to address the needs of ELLs throughout the curriculum. De Oliveira and Shoffner (2009) posited that the teaching of ELLs as addressed with future content-area teachers (e.g., English language arts teachers) has generally resided under the umbrella of "teaching diverse students." Yet, as classrooms in the United States become more culturally and linguistically diverse, perhaps it is too general to characterize ELLs under such broad a category.

\section{Culturally responsive teaching as the foundation of English teachers' work with}

English language learners. There is a consistent view in English education that culturally responsive teaching (Gay, 2000) and culturally relevant pedagogy (Ladson-Billings, 1994) can 
be conceived of as foundations of preservice teachers' work with ELLs. Gay (2000) described culturally responsive teaching as:

... using the cultural knowledge, prior experiences, frames of reference, and performance styles of ethnically diverse students to make learning encounters more relevant to and effective for them. It teaches to and through the strengths of these students. It is culturally validating and affirming. (p. 29).

Preservice teachers' knowledge and understanding of culturally responsive teaching supports ELLs literacy learning and development, reading comprehension, and writing abilities. Dooly's (2007) research of understanding how culturally responsive teaching provided a foundation for preservice English teachers' approach to teaching ELLs established the need for teachers' construction of teaching frameworks rooted in equity perspectives on linguistic and cultural diversity (as opposed to deficit perspectives of teaching English language learners).

Culturally responsive teaching is highlighted as a foundation for good teaching of all students (Gay, 2000), and therefore, English teachers can utilize such a framework to reach diverse groups of students. Yet, English teachers' lack of experience in working with children whose first language is not English often prevents them from having an accurate appraisal of what such culturally responsive practices might look like in the classroom (Rubinstein-Avila, 2003). Therefore, beginning English teachers' work in learning about English language learners must extend beyond scenarios presented in teacher education classes and programs.

\section{Preservice English teachers' understanding of the changing role of the English}

teacher. Finally, addressing preservice English teachers' role in teaching ELLs includes embracing the notion of a changing role of the English teacher in US schools. In English teacher education, the changing student demographics in US schools have prompted some (Boyd et al., 
2006; Kirkland, 2008) to call for a "new" English teacher education; one that, in part, acknowledges the multiple languages and literacies that students bring to the classroom. The role and identity of the teacher in the new English education, then, must always be seen in relation to the students they teach.

A redefined role of English teacher can sometimes be at odds with a more traditionally defined role (see Yoon, 2007), and de Oliveira and Shoffner (2009) noted that "preservice [English] teachers indicate that they are often nervous about teaching ELLs, concentrating on the difficulties posed, rather than the possibilities offered, by diverse learners in the classroom" (p. 100). Thus, it appears important to address differentiation and modification from an additive, rather than a subtractive, standpoint, when providing a foundation for work with ELLs.

The studies that CEE cites in its position statement (2005) on teaching culturally and linguistically diverse students provide an imperative for addressing the needs of diverse students in today's classroom. Yet, there are currently few documented accounts (de Oliveira \& Shoffner, 2009; Glenn \& Gort, 2010) of how the field should address the purpose of the English methods class with regard to teaching English language learners. NCTE/ CEE embraced the position that the role and responsibility of English teachers must include the teaching of ELLs, thus preparing prospective English teachers also to support this role becomes part of the mission of the English teacher educator. As new English teachers acknowledge language variances evident in classroom demographics, they must also address pedagogical change in the teaching of English language arts.

\section{Integrating Technology into the English Language Arts Methods Class}

Technologies and the new media they produce ask users to move past reading and responding to print texts to also reading and responding to digital texts. As new digital devices 
become available, students learn to read and write in languages that are specific to each technology's base of communication. This phenomenon asks instructors to be literate in ways most English Language Arts teacher preparation programs never anticipated. The proliferation of technology and new media pressures teachers to change their teaching of English, thus pressing teacher educators to change how to prepare preservice teachers for English classrooms. Swenson, Young, McGrail, Rozema and Whitin (2006) observed, "With the growing range of texts available to students today, literacy skills have expanded to reading images, codes, and sounds in addition to words" (p. 223). The explosion of technology in contemporary lives has moved English instructors to consider a new literacy (Swenson et al. 2006; Yagelski 2005), one that encompasses reading not only traditional print publications but also reading media objects and the people to whom they refer, social practices, critical perspectives, and other situational instances that require meaning-making strategies (Author 1, 2007; Bruce \& Levin 2003; Kinzer \& Leander 2003; Merkley, Schmidt \& Allen 2001). For English language arts instructors and teacher educators, this phenomenon prompts the question: When educating English instructors to support their own students to become literate members of society, what new literacies, new media, and technologies integrate effectively into classroom practices? This question drives much of the research in the study of English language arts education.

It is noteworthy to mention that the "Annual Annotated Bibliography of Research in the Teaching of English" published in Research in the Teaching of English each November has grown from a total of fifteen pages in 2003 to eighty-eight pages in 2010, largely due to the increased number of studies being published that investigate digital/technology tools in the teaching of English (Beach et. al., 2010). Many of these studies concerned the efficacy of employing technology in classroom practices more so than in the methods classroom, albeit quite 
an impressive number of studies do explore this work with preservice teachers. Therefore, due to the volume of related articles for this section, after reading all abstracts and conclusions, the author established the categories used below and read all the articles specifically connected to the methods course or to preparing teacher candidates. The author selected 17 studies that seemed representative of current research trends and that provided insight into the conditions and decisions to integrate technology into the English language arts that aligned with other areas explored in this review.

The following review explores the principles, frameworks and practices identified as methods to achieve effective technology integration in the ELA. The studies referenced are divided into practices that examine supportive open or collaborative learning spaces and closed or individualized learning spaces.

\section{Effective practices in the integration of technology in the English language arts}

methods class: Principles and frameworks: In 2000, Pope and Golub proposed a set of principles and practices for integrating technology into English language arts classrooms, in particular the methods' classroom, to prepare future English teachers for the change in instruction that seemed imminent to them. Although not a study, this article became significant because it challenged researchers to explore and test the 21 st-century literacy practices that were changing communication models and the content of the English language arts classroom (Bruce \& Levin 2003; Kinzer \& Leander 2003; Merkley, Schmidt \& Allen 2001; Swenson et al. 2006; Yagelski 2005). Correspondingly, Young and Bush (2004) proposed a critical approach and pedagogical framework to maximize the benefits of technology to teach writing and literacy. They observed, 
To integrate technologies in a classroom without an understanding of context risks using technologies ineffectively or inappropriately, thus wasting opportunities for new learning experiences and, potentially, vast amounts of money spent on underutilized technological resources (Young \& Bush, 2004, p. 7).

Therefore, they proposed a critical framework to discern whether or not technology was being integrated into a lesson with "thoughtful and informed use" (p. 9), asking users to keep the pedagogical implications of the technology in the forefront as users considered its impact on instruction, skills, content and literacy. They developed their framework after surveying preservice teachers in methods classes and inservice teachers who were participating in a writing project site. They stressed that the incorporation of technology into learning should take into account equity and access, empowerment, transparency, expand literacy skills, and enhance critical learning. They warned that technology should not replace teachers or complicate conventional modes of communication that work well. They especially urged teacher educators to model effective practices of teaching with technology in their methods classes.

In a three-year, mixed methods longitudinal study, Author 1 (2007) took on the challenges to model effective technology integration in her language arts methods classes by conducting them in a computer lab, and learned that the choices preservice teachers in English made to integrate technology into their practice indicated what they valued about teaching, their comfort with technology, how they conceived and envisioned their content knowledge, and where they found support to engage in experimentation. Teacher candidates' decisions to practice with or without technology resembled the choices made by members of most English departments, with these decisions reflecting specific teacher values about the discipline and how those values are expressed in practice. Technology use or rejection indicated teacher candidates' 
comfort with active and/or collaborative learning environments. The ease with which preservice teachers learned a technology that would enhance a lesson communicated dispositions and/or attitudes about teacher candidates' comfort in the classroom, their philosophies about classroom management, their perception of equal access, and their impressions of technology being relevant to real-world experiences.

Similarly, in a five-year longitudinal study that examined work samples and reflective data, Thieman (2008) explored the extent to which preservice teachers integrated technology into their instructional planning after taking a stand-alone educational technology course offered over two semesters. Data were analyzed through the lens of the National Educational Technology Standards and Performance Standards for Teachers (NETS-T) and National Educational Technology Standards for Students (NETS-S) as designed in 2000 by the International Society for Technology in Education (ISTE). Thieman learned that $85 \%$ of the preservice teachers who participated in the study integrated technology into their instructional design to some varying degree often dependent on grade level. Data revealed that technology was used to emphasize "creativity and innovation, communication and collaboration, and research and information fluency. There was little evidence that students used technology in other areas [. . .] including critical thinking, problem solving, and decision-making” (Thieman, 2008, p. 362).

These studies, although they called for the integration of technology into the content of the ELA classroom and explored how pre- and inservice teachers might effectively do so, did not address the purpose of the methods class where the study took place and how it fit into the broader English education program. It is unclear whether the technology skills and content under examination are infused throughout programs or are offered in one focused technology class. CEE guidelines suggest that technology should be integrated throughout the K-12 ELA 
curriculum to inform the way people think about texts, language and literacy (Swenson et. al, 2005).

\section{Open or collaborative learning spaces in the ELA methods classroom: The} effectiveness of wikis, blogs, discussion boards and online tutoring. Recent studies of English language arts methods classes examined the use of Web 2.0 applications to "harness a group's collaborative, creative energy to produce shared knowledge that benefits everyone" (Evans, 2006, as quoted in Matthew, Felvegi \& Callaway, 2009, pp. 51). Since most Web 2.0 applications supported collaborative and social environments on the Internet, many of these spaces became places outside physical classrooms to provide non-traditional field experiences to preservice teachers. Additionally, some teacher education programs used technology and new media to offer other field opportunities to preservice teachers who would otherwise not have had these experiences because of scheduling problems and inconvenient distances. Some programs created virtual places for online tutoring between teacher candidates with elementary and secondary school students in the community, while other teacher education programs used similar spaces for cross-disciplinary and cross-global collaboration, as well as the more typical place for virtual discussion between face-to-face class meetings.

Matthew, Felvegi \& Callaway (2009), using case-study methodology, examined the use of wikis and how they affected the learning of course content by preservice teachers. Through a wiki, preservice teachers learned an "appreciation of their classmates' knowledge and recognized it as a valuable resource" (Matthew, Felvegi, \& Callaway, 2009, pp. 67), by creating a collective synthesis of knowledge gained in that class with that gained from other courses across their programs. 
In another study (Dymoke \& Hughes, 2009), a wiki was also used to build collaborative content knowledge about poetry for preservice teachers. The investigators examined their students' abilities to write in a digital medium and how it impacted their perceptions of themselves as writers and teachers of poetry writing. The wiki space became a "new" space to collaborate with preservice teachers from the UK and Canada to write together. They conclude: ... it is evident that some preservice teachers have begun to write poetry in a variety of poetic forms, to gain confidence in their ability to write poetry and to reflect on themselves as writers. They have witnessed and experimented with methods of intervening in drafts - experiences that could enhance their own creativity, criticality and emerging classroom craft. Some members of the cohort have developed their technological skills in digital and multimodal communication through use of written, visual and sound modes [to various degrees of competence] (Dymoke \& Hughes, 2009, pp. 101).

Unfortunately, by composing in a new space, the original poetry written in the wiki seemed to linger there and not affect the authors' abilities to write more effectively.

Lee and Young (2010) examined how preservice teachers use Web 2.0 technologies (wikis and blogs) in their methods class and how learning these applications affected their preparation. By aligning their findings with six of the models of new literacies identified in Jenkins et al. (as quoted in Lee \& Young 2010), Lee and Young found that incorporating wikis and blogs into their English/Social Studies methods class supported opportunities for collaboration and active learning through a constructivist stance and created a community of practice by “(1) enabling the valuing of multiple ideas in civic contexts; (2) encouraging 
discourse on emerging ideas; and (3) modeling ways of thinking about new ideas" (2010, Conclusion, Implications section, para. 4).

By examining large-group online discussion forums over a period of six years, Ryan and Scott (2008) learned that the most effective way to spark professional discourse among preservice teachers is by employing case-study scenarios that allow teacher candidates to move into the role of "expert" as they develop critical literacy skills. Ryan and Scott's findings reinforced that "online environments are democratic in that they allow participants who do not speak in classes an opportunity to have a voice and no one dominates the discussion (BradfordSmith, Smith \& Boone, 2000; Swan, 2001)" (Ryan \& Scott, 2008, p. 1639).

Houge and Geier (2009) examined the effectiveness of using videoconferencing for oneon-one tutoring in reading instruction by tracking improvement of the tutees through pre- and post reading and spelling scores. This experience was an opportunity for university students to apply the skills they acquired in a teaching reading class and for the $4-12^{\text {th }}$ grade students to improve their reading abilities through the use of distance education technology. Findings suggested that "one-to-one literacy instruction via videoconferencing technology can be an engaging and effective means to assist adolescents with comprehension while reading with appropriate accuracy and fluency" (Houge \& Geier, 2009, pp. 161).

It seems that studies such as these addressed how aspects or specific classes within English teacher preparation programs have met the changing contexts that technology has imposed on literacy practices but not on a grand scale. Many of these studies seemed to take place in isolated instances within a program instead of across a program. How are the theoretical and pedagogical approaches taught in a program affected by this integration and how does it affect the effectiveness of the preservice teachers as they move into their internships? 


\section{Closed or individualized learning spaces in the ELA methods classroom: The effectiveness of desktop applications, e-portfolios, multimodal and multimedia software.} Portfolio assessment has become the standard practice in many teacher education programs to evaluate a teacher candidate's competency. These practices are particularly common in English studies with many English teacher education programs moving to online portfolios to provide convenient access to large collections of artifacts and data, solving the problem of continuing a means of assessment that has long been valued in the teaching of writing. Despite this convenience, in moving to online portfolios, teacher education programs have been challenged to ask their teacher candidates to pay for applications that allow access to their program's instructors and, in some cases, the state's teacher licensing body. In addition to integrating technology into a methods course and purchasing online portfolio applications, many teacher education programs require some type of instructional technology course that asks students to not only explore Internet applications but also to become adept at desktop applications and multimedia software like Microsoft PowerPoint, Windows MovieMaker or Apple's iMovie, WebQuest, Adobe Dreamweaver and the like.

Seo, Templeton, and Pellegrino (2008) examined the effects of multimedia on projectbased learning that affected the content knowledge of preservice teachers. The researchers found that the technology methods employed in a project-based learning course promotes a "learnercentered constructivist model, helps students develop skills for retrieving information from multiple resources and motivates students intrinsically by providing a sense of ownership and accomplishment" (Seo, Templeton, \& Pellegrino, 2008, p. 260), much like many of the studies that explored the integration of Web 2.0 technology. Data revealed that multimedia-assisted, project-based learning contributed to increased content knowledge and improved technology 
skill for the preservice teachers. Additionally, the subjects formed more sophisticated teaching philosophies though this work, despite some obstacles with the technology and its access.

In a course similarly constructed to Seo et al.'s, McVee, Bailey, and Shanahan (2008) studied how technology integration affected the learning of their pre- and inservice graduate students who were taking a fifteen-week class on new literacies and technology. This small group of "traditional” aged students completed digital projects using Internet browsers, PowerPoint, WebQuests, Dreamweaver, iTunes, iMovie and others. Data revealed that teacher educators "must foster environments to share problem-solving and distributed learning, to support design and multimodal redesign of texts, and to explore literacy and technology as transactional processes" (McVee et al., 2008, p. 197) although these situations required support for the teacher candidates to successfully integrate technologies into their practices. The researchers concluded that "the daily decisions that teachers make and the instruction that results from those decisions are often far more important than the technology that teachers use to enact their instruction plans" (McVee et al., 2008, p. 208).

Dempsey, PytlikZillig, and Bruning (2009) examined preservice teachers' writing assessment abilities following Spandel's Six Traits model through the online tutoring of fourth grade writers using a software called ThinkAboutIt specifically designed for this project by the researchers' university's instructional technology center. The software provided the teacher candidates with feedback about their assessment practices and provided them with access to "expert" models of assessment in addition to assessment suggestions from their peers. The researchers learned that the preservice teachers' abilities to assess writing improved overtime along with an increased confidence in their own abilities to assess writing by using the language of this program. 
Figg and McCartney (2010) reported on the impact of a community partnered digital storytelling initiative conducted through the "Amazing Technologists Think Teach and Create Stories of Excellence" (ATTTCSE) Project, a project designed for the second year of a threeyear study that explored the integration of writing, technology and diversity through the TPACK model of technology enhanced field experiences. In addition to other subjects and data collection, while enrolled in their university's instructional technology course, the researchers' studied how teacher candidates facilitated the project's digital storytelling summer workshops, as an alternative to their field experiences. Despite their assertions that they learned more about facilitation than teaching through this experience, the researchers' data analysis concluded that the teacher candidates benefited from this alternative experience. Other studies in digital storytelling (Tenero, 2006), digital video composing (Miller, 200), and e-reading and writing (Luce-Kapler \& Dobson, 2005) and their impact on the competency of teacher candidates proliferate. Findings indicate there is a need for educating teacher candidates to understand differences in print and digital media in addition to establishing some level of comfort with the hardware and software that create it.

Lastly, Lai and Calandra (2010) learned through a study of reflective writing practices that e-portfolios could be used as "computer-based scaffolds to augment reflective practice in technology-enhanced educational systems" (Lai \& Calandra, 2010, p. 421), findings that also require knowledge of hardware and software to create assessment material that is easily accessible to the teacher educators who will be evaluating it - a situation that requires the development of new skills on many levels.

It is important to note that many of the studies reviewed in this section did not take place in the ELA methods class but one designed to explore the competency of using technology for 
teaching purposes. It is unclear how many of these studies are connected to the ELA programs' curriculum and if these skills, conceptual and practical, are fostered or developed elsewhere in the education of a teacher candidate.

\section{Technology integration into the $21^{\text {st }}$ century English language arts methods class.}

There are numerous studies examining how technology should be integrated into the methods class in the $21^{\text {st }}$ century; but in reviewing these studies, there are many unanswered questions as to how they address the broader conversation about preparing preservice teachers to teach English and what teaching practices result from the various forms technology takes in different teacher education programs.

Another, more salient question, foreshadowed much of the discussion about integrating technology into the ELA methods class: How will technology affect whether students are educated either face-to-face or online? It seems many of the studies reviewed examined technology as it is used to support a traditional classroom - whether it is taught in a computer lab, computer enhanced space or traditional classroom. What will the methods course look like in the future as many universities are pressured to conduct learning online (a conversation happening also at the secondary level)? If technology supports more collaborative space for active learning environments, will English teacher educators move their methods classes online or resist this instructional approach? How can English teacher educators align traditional faceto-face classroom approaches to online learning to best help students study English? Will market forces drive these decisions or will future studies determine the best approaches to learning? How many university methods classrooms incorporate technology into the teaching of English and what does that look like across programs? As a review of the literature demonstrates, many of the technology learning experiences being studied take place in instructional technology 
classes and not the ELA methods classes. Thus, there is a need to learn how technology is used in the ELA methods class and how it affects programmatic decisions to meet the changing contexts of the 21 st century.

\section{Discussion}

As the authors of this paper indicate, with the exception of studies in the area of technology integration and the teaching of literacy skills, there is little research on how English teacher preparation is changing to meet the curricular, cultural, political, and economic challenges faced by the English language arts discipline, its teachers and its teacher educators since the last major study was published in 1995. This review has emphasized that the field must move forward to consider how methods courses need to evolve as a way to respond to new forms of literacy, new technologies, more diverse student populations, an increased state of accountability for schools, and increased emphasis on field/ university connections.

A move to a disciplinary view of literacy (Moje, 2008) bears great promise for English teacher education. As of yet, however, the few pieces of research on the preparation of English teachers for literacy instruction in methods classes indicate that there is a need for balance between the instructional models presented in methods courses and the constraints that teachers will face in schools; these constraints can influence the uptake of pedagogy for literacy instruction. It is quite possible that explicit teaching of both conceptual and practical information about literacy instruction is necessary in order for preservice teachers to use these instructional methods in their student teaching and in their teaching careers (Grossman, Smagorinsky\& Valencia, 1999). Future research on the preparation for English teachers to teach reading and writing might focus on how English teacher educators could best provide these conceptual and practical tools. 
Field/clinical experiences continue to be a valued component of teacher education programs, especially when supported by methods coursework (Garner \& Rosen, 2009). Further understanding of the explicit connections between the methods course and accompanying field experiences would inform the field of English education of the nature of these theory/ practice connections. Researching the pedagogical shifts that beginning teachers experience as a result of the connections between field experiences and methods course assignments would make a solid contribution to the field.

Preservice teachers are facing a different curricular and regulatory landscape than did most of their university instructors. Current students are the first generation to be schooled in a high-stakes testing environment, meaning their "apprenticeship of observation" (Lortie, 1975) was often oriented more towards test preparation and meeting content standards than that of earlier generations (Brown, 2010). If English education programs are to address the realities of the K-12 classrooms that teacher candidates are entering, then teacher educators need to research how to prepare preservice teachers to use standards and assessments in ways that will enable them to engage their own students meaningfully in the core concepts of English language arts.

Although culturally responsive teaching (Gay, 2000) has laid a solid framework for approaching the teaching of diverse students in English classrooms, there is little research that addresses how the linguistic and cognitive dimensions of language learning might be addressed with preservice teachers who are learning to teach English. If English methods continues to move toward the inclusion of methods of teaching of English language learners (ELLs), English education would benefit from further guidance on what aspects of language learning preservice English teachers might most need to effectively teach students whose first language is not English. 
Despite the wide range of studies examining the integration of technology into teaching, few examined the impact on the ELA methods class and how it affected the organization of a program and addressed the changes of the teaching context in the 21 st century. Will middle and secondary school student English education move online and how will this impact the preparation of English teachers in the future?

As the findings of this review suggest, as the contextual landscape surrounding English education has changed, methods courses have begun to respond to these changes. Yet, capturing a large-scale portrait of such changes appears timely for the field.

\section{Methods Studies in Context: (Dis)Connections Across Programs of English Education}

There were studies that looked at particular aspects of the content being taught in the methods course or how a particular field component was designed and experienced, but the study of how the methods course fit into a teacher education program, as well as its role within the program, was rare in the literature. Current studies rarely placed the methods course in the context of the larger teacher education program or spoke specifically about the entire methods course. Perhaps this situation is due to changes in teacher preparation that made the methods course less dominant in the overall field. Methods courses might not be the place where preservice teachers address the issues related to integrating technology or address the needs of English language learners. An examination of program websites in different states revealed that many programs do not offer subject-specific methods courses. In some states, only general secondary licenses were awarded (US DOE, 2012), and even in states that grant subject-specific licenses, some smaller programs used a BA in English and placement in an English classroom along with general secondary methods courses as qualification for licensure. Moreover, some alternative programs that provided little to no subject-specific preparation seemed to be 
multiplying rapidly - in some states, preparing more students than the traditional programs housed in colleges and universities (US DOE, 2012). However, the relationship between preparation in the subtopics and the structures of pre-service programs was also understudied.

As a result of completing this review, it is apparent to the authors of this paper that the discipline does not have a sufficiently clear portrait of how English teacher education has responded to the two revisions of the guidelines for teacher preparation, the redefinition of what constitutes methods coursework in and across programs, the explosion of culturally and linguistically diverse learners, the demands of assessment and accountability, and the integration of the field experience with content.

\section{English Teacher Education and Its Methods Course in the $21^{\text {st }}$ Century}

It is time for a large-scale account of the requirements and experiences new English teachers encounter as they prepare for licensure - an account that categorizes the theoretical and pedagogical approaches that English education programs teach as effective practices. Such a study should be a new study of how English teachers are taught that differs somewhat from Smagorinsky and Whiting (1995), a work still characterized as reflecting current methods in content and pedagogy (e.g., Hillocks, 2011). Increasingly, the methods class(es) is inextricable from its curricular context, as the very idea of the methods course changes or becomes obsolete, and as programs work to make their content more coherent. As pointed out earlier in this paper, some programs have a single subject-specific methods course right before or during the student teaching semester; some have none. However, a number have several semesters of courses, housed in English and curriculum departments, that perhaps build on each other in a spiral fashion, or that address elements of the English language arts (i.e., "Composition for English Teachers" or "Teaching Literature in the Secondary English Classroom"). In addition, changes 
are being made to courses in relation to forces both internal (e.g., changing definitions of texts, demands of inclusion) and external (increased numbers of English language learners, changes in technology) to the contexts in which English teachers are being prepared. These forces may or may not be reflected in the language of a syllabus, as were used to determine content in the Smagorinsky and Whiting study in 1995. Therefore, to more fully understand what is being taught in a methods course, to determine the current national portrait of English teacher education, work needs to be done to clarify the changes in concept and practice that have taken place in secondary English teacher education programs in response to the changing curricular, cultural, political, and economic contexts since 1995.

As teachers continue to be demonized in the press and marginalized by people in power outside the profession, it becomes imperative for English teacher educators to answer some of the following questions: What preparation do English teachers receive? What is the consensus of English teacher educators regarding what pedagogical content knowledge looks like in English teacher education (Ball, Thames \& Phelps, 2008; Grossman, 1990; Shulman, 1987)? How are the concepts of what is necessary changing in a time of globalization, growing diversity in K-12 classrooms, and technological innovation? How are practices changing with them?

There is much work to be done by English teacher educators and researchers to address these questions, to update and enhance the work of Smagorinsky \& Whiting (1995), and to engage in conversation with educators in the other disciplines in teacher education who are also coming to terms with these questions. 
Author 1. (2007). Blinded for review.

Author 2. (2007). Blinded for review.

Author 2. (2013). Blinded for review.

Author 3. (2011). Blinded for review.

Agee, J.M. (1996). "I was kind of hoping for a woman": Issues of lived experience in the preservice-cooperating teacher relationship. English Education, 28 (4), 280-302.

Agee, J. M. (1997). Readers becoming teachers of literature. Journal of Literacy Research, 29, 397-431. doi:10.1080/10862969709547966

Agee, J. M. (1998). Negotiating different conceptions of reading and teaching literature in a preservice literature class. Research in the Teaching of English 33, 85-120.

Akyol, H., \& Ulusoy, M. (2010). Pre-service teachers' use of reading strategies in their own readings and future classrooms. Teaching and Teacher Education, 26, 878-884. doi:10.1016/j.tate.2009.10.026

Albers, P. (2002). Praxis II and African American teacher candidates (or, Is Everything Black Bad ?). English Education, 34(2), 105-125.

Alger, C. (2009). Content area reading strategy knowledge transfer from preservice to first-year teaching. Journal of Adolescent \& Adult Literacy, 53, 60-69. doi:10.1598/JAAL.53.1.6

Allen, J. \& Hermann-Wilmarth, J. (2004). Cultural construction zones. Journal of Teacher Education 55, 201-213. doi:10.1177/0022487104263080

Alsup, J., Emig, J., Pradl, G., Tremmel, R., Yagelski, R. et al. (2006). The state of English Education and a vision for its future: A call to arms. English Education, 38, 278-294.

Anagnostopoulos, D. (2003). Testing and student engagement with literature in urban classrooms: A multilayered perspective. Research in the Teaching of English, 38, 177- 
212.

Anagnostopoulos, D., Smith, E., \& Basmadjian, K. (2007). Bridging the university school divide: Horizontal expertise and the "two-worlds" pitfall. Journal of Teacher Education, 58, 138-152. doi:10.1177/0022487106297841

Angelotti, M., Cappella, D, Kelly, P.K., Pope, C., Beal, C., \& Milner, J. (2001). Preservice teacher research: How viable is it? English Education, 34(1), 79-84.

Applebee, A. N. (1993). Literature in the secondary school: Studies of curriculum and instruction in the United States. Urbana, IL: NCTE.

Applebee, A.N. \& Langer, J. (2009). What is happening in the teaching of writing? English Journal, 98 (5), 18-28.

Applebee, A.N., Langer, J., Nystrand, M., Gamoran, A. (2003). Discussion-based approaches to developing understanding: Classroom instruction and student performance in middle and high school English. What are effective schools doing? American Educational Research Journal 40, 685-730. doi:10.3102/00028312040003685

Au, K. H. \& Raphael, T. E. (2000). Equity and literacy in the next millennium. Reading Research Quarterly, 35, 170-1. doi: 10.1598/RRQ.35.1.12

Aukerman, M., Belfatti, M., \& Santori, D. (2008). Teaching and learning dialogically organized reading instruction. English Education, 40, 340-364.

Baber, C. (1995). Leaders of color as catalysts for community building in a multicultural society. Theory and Research in Social Education, 23, 342-54.

Baker, E. L., et al. (2010). Problems with the use of student test scores to evaluate teachers. EPI Briefing Paper \# 278. Washington, D.C.: Economic Policy Institute. Retrieved 1/22/11 from http://epi.3cdn.net/b9667271ee6c154195_t9m6iij8k.pdf 
Ball, D. L., Thames, M. H. \& Phelps, G. (2008). Content knowledge for teaching: What makes it special? Journal of Teacher Education, 59, 389-407. doi:10.1177/0022487108324554

Basmadjian, K.G. (2005) Learning to lead discussions: Context, conflict, and community. Doctoral dissertation. Available from Dissertation Express database (UMI No. 3189608).

Basmadjian, K.G. (2008). Watching what we say: Using video to learn about discussions. English Education, 41, 13-38.

Beach, R., Brendler, B., Dillon, D., Dockter, J., Ernst, S., Frederick, A., . . Janssen, T. (2010). Annual annotated bibliography of research in the teaching of English. Research in the Teaching of English, 45(2), AB1-AB88. Retrieved from: http://www.ncte.org/library/NCTEFiles/Resources/Journals/RTE/0452nov2010/RTE0452Annotated.pdf

Beach, R., Thein, A. H., \& Webb, A. (2012). Teaching to exceed the English language arts Common Core State Standards: A literacy practices approach for 6-12 classrooms. New York: Routledge.

Black, R. (2009). English-language learners, fan communities, and 21st century skills. Journal of Adolescent and Adult Literacy, 52, 688-697. doi:10.1598/JAAL.52.8.4

Boutte, G. (1999). Multiculturalis: Moral and educational implications. Dimensions of Early Childhood, 28, 9-16.

Boyd, F.B., Ariail, M., Williams, R., Jocson, K., Sachs, G.T., \& McNeal, K., et al. (2006). Real teaching for real diversity: Preparing English language arts teachers for $21^{\text {st }}$ century classrooms. English Education, 38, 329-350.

Boyd, D., Grossman, P., Lankford, H., Loeb, S., \& Wyckoff, J. (2009). Teacher preparation and student achievement. Educational Evaluation and Policy Analysis 31, 416-440. DOI: 
$10.3102 / 0162373709353129$.

Brown, C. P. (2010). Children of reform: The impact of high-stakes education reform on preservice teachers. Journal of Teacher Education, 61, 477-491. doi:

$10.1177 / 0022487109352905$

Bruce, B. \& Levin, J. (2003). Roles for new technologies in language arts: Inquiry, communication, construction, and expression. In J. Flood, D. Lapp, J.R. Squire, \& J.M. Jensen (Eds.), Handbook of research on teaching the English language arts (pp. 649657). Mahwah, NJ: Lawrence Erlbaum Associates.

Burbank, M., Bertagnole, H., Carl, S., Dynak, J., Longhurst, T. \& Powell, K. (2005). UniversityDistrict partnerships and the recruiting of tomorrow's teachers: A grassroots effort for preparing quality educators through teaching academies. The Teacher Educator, 41, 5469.

Burch, C. B. (1999). When students (who are preservice teachers) don't want to engage. Journal of Teacher Education 50, 165-172. doi:10.1177/002248719905000302

Bush, J. (2005). Teaching English in the world: Keeping new English teachers young. The English Journal. 95(2), 105-8.

Capraro, M.M., Capraro, R.M. \& Helfeldt, J. (2010). Do differing types of field experiences make a difference in teacher candidates' perceived level of competence. Teacher Education Quarterly, 37, 131-154.

CEE (Conference on English Education). (2005). Supporting Linguistically and Culturally Diverse Learners in English Education. CEE Position Statements. Retrieved from: http://www.ncte.org/cee/positions/diverselearnersinee

CEE (Conference on English Education). (2008a). What is English Education? CEE Position 
Statements. Retrieved from: http://www.ncte.org/cee/positions/whatisenglished

CEE (Conference on English Education). (2008b). What Do We Know and Believe about the Roles of Methods Courses and Field Experiences in English Education? CEE Position Statements. Retrieved from: http://www.ncte.org/cee/positions/roleofmethodsinee

Cercone, J. (2009). We're smarter together: Building professional social networks in English education. English Education, 41(3), 199-206.

Clark, C.T. (2010). Preparing LGBTQ-allies and combating homophobia in a U.S. teacher education program. Teaching and Teacher Education, 26, 704-713. doi:10.1016/j.tate.2009.10.006

Cohen, J. (2007). A case study of a high school English-language learner and his reading. Journal of Adolescent and Adult Literacy, 51, 164-175. doi:10.1598/JAAL.51.2.7

Common Core State Standards Initiative (CCSSI). (2010). Common Core State Standards for English language arts and literacy in history/social studies, science, and technical subjects. Washington, D.C.: National Governor's Association and the Association of Chief State School Officers.

Retrieved from http://www.corestandards.org/ELA-Literacy

Darling-Hammond, L. \& Bransford, J. (2005). Preparing teachers for a changing world: What teachers should learn and be able to do. San Francisco: Jossey Bass.

Dempsey, M. S., PytlikZillig, L. M., \& Bruning, R. H. (2009). Helping preservice teachers learn to assess writing: Practice and feedback in a Web-based environment. Assessing Writing, 14, 38-61. doi:10.1016/j.asw.2008.12.003

de Oliveira, L. \& Athanases, S. Z. (2007). Graduates' reports of advocating for English language learners. Journal of Teacher Education, 58, 202-215. 
doi:10.1177/0022487107299978

de Oliveira, L. \& Shoffner, M. (2009). Addressing the needs of English language learners in an English education methods class. English Education, 42, 91-111.

DeStigter, T. (1998) A good gang: Thinking small with pre-service teachers in a Chicago barrio. English Education, 31, 65-87.

Dickson, R. \& Smagorinsky, P. et al. (2006). Are methods enough? Situating English education programs within the multiple settings of learning to teach. English Education, 38, 312328.

Donahue, D. (2003). Reading across the great divide: English and math teachers apprentice one another as readers and disciplinary insiders. Journal of Adolescent \& Adult Literacy, 47, 24-37.

Dong, Y.R. (2008). Productive Tensions: Student Teachers' Handling of Sociocognitive Conflicts

during the Classroom Discussion. English Education, V40 N3.

Dooley, C. M., \& Assaf, L. C. (2009). Contexts matter: Two teachers' language arts instruction in this high-stakes era. Journal of Literacy Research, 41, 354-391. doi:10.1080/10862960903133743

Dooly, M. (2007). Constructing differences: A qualitative analysis of teachers' perspectives on linguistic and cultural diversity. Linguistics and Education, 18(2), 142-166. doi:10.1016/j.linged.2007.05.001

Dudley-Marling, C., Abt-Perkins, D., Sato, K., \& Selfe, R. (2006). Teacher quality: The perspectives of NCTE members. English Education, 38(3), 167-193.

Dymoke, S., \& Hughes, J. (2009). Using a poetry wiki: How can the medium support preservice 
teachers of English in their professional learning about writing poetry and teaching poetry writing in a digital age? English Teaching: Practice and Critique, 8(3), 91-106.

Fairbanks, C.M., Freedman, D, \& Kahn (2000). The role of effective mentors in learning to teach. Journal of Teacher Education, 51, 102-112.

Fecho, B. (2003). Conversations from the commissions: Untangling our predicaments: Inquiring into methods courses. English Education, 36, 86-89.

Fecho, B, Price, K., and Read, C. (2004). From Tununak to Beaufort: Taking a critical inquiry stance as a first year teacher. English Education, 36(4), 263-288.

Feiman-Nesmer, S., and Buchmann, M. (1989). Pitfalls of experience in teacher preparation. Teachers College Record, 87, 53-65.

Fernsten, L.A. (2008). Writer identity and ESL learners. Journal of Adolescent and Adult Literacy, 52, 44-52. doi:10.1598/JAAL.52.1.5

Figg, C. \& McCartney, R. (2010). Impacting academic achievement with student learners teaching digital storytelling to others: The ATTTCSE digital video project. Contemporary Issues in Technology and Teacher Education, 10(1). Retrieved from http://www.citejournal.org/vol10/iss1/languagearts/article3.cfm

Finders, M.J. \& Rose, S.K. (1999). "If I were the teacher": Situated performances as pedagogical tools for teacher preparation. English Education, 31, 205-222.

Fisher, D., Rothenberg, C. \& Frey, N. (2007). Language learners in the English classroom. Urbana, IL: NCTE.

Fleischer, C. \& Fox, D. (2002). Toward a path of thoughtfulness: Questioning our methods in English education. English Education, 34, 255-257.

Fleischer, C. \& Fox, D., eds. (2004). Themed issue: Teacher education in language arts and 
literacy in the era of "No Child Left Behind." English Education, 36, no. 2.

Frederickson, J. E. (2011). How educators use policy documents: A misunderstood relationship. Language Arts Journal of Michigan 26 (1), 43-48.

Garner, G \& Rosen, C. (2009). Strengthening partnerships and boosting conceptual connections in preservice field experiences Teaching Education, 20, 329-342. doi: $10.1080 / 10476210902849958$

Gay, G. (2000). Culturally responsive teaching: Theory, research, and practice. New York: Teachers College Press.

Gilbert, Linda. (2005). What helps beginning teachers? Educational Leadership. 62(8), 36-39.

Glenn, W. J. (2007). Real writers as aware readers: Writing creatively as a means to develop reading skills. Journal of Adolescent \& Adult Literacy, 51, 10-20.

doi:10.1598/JAAL.51.1.2

Goe, L., Bell, C., \& Little, O. (2008). Approaches to evaluating teacher effectiveness: A research synthesis. Washington, DC: National Comprehensive Center for Teacher Quality.

Gordon, M. (2008). Between constructivism and connectedness. Journal of Teacher Education 59, 322-331. doi:10.1177/0022487108321379

Gort, M. \& Glenn, W. J. (2010). Navigating tensions in the process of change: An English educator's dilemma management in the revision and implementation of a diversityinfused methods course. Research in the Teaching of English, 45, 59-86.

Grabill, J.T. \& Hicks, T. (2005). Multiliteracies meet methods: The case for digital writing in English education. English Education, 37, 301-311.

Graham, P. (1997). Tensions in the mentor teacher-student teacher relationship: 
Creating productive sites for learning within a high school English teacher education program. Teaching and Teacher Education, 13, 513-527.

Graham, P. (1998). Teacher research and collaborative inquiry: Teacher educator and high school English teachers. Journal of Teacher Education, 49, 255-265.

Graham, P. (2005). Classroom-based assessment: Changing knowledge and practice through preservice teacher education. Teaching and Teacher Education, 21, 607-621. doi:10.1016/j.tate.2005.05.001

Grant, R.A. \& Wong, S.D. (2003). Barriers to literacy for language-minority learners: An argument for change in the literacy education profession. Journal of Adolescent and Adult Literacy, 46, 386-394.

Groenke, S. (2008). Missed opportunities in cyberspace: Preparing preservice teachers to facilitate critical talk about literature through computer-mediated communication. Journal of Adolescent \& Adult Literacy, 52(3), 224-233. doi:10.1598/JAAL.52.3.5

Grossman, P.L. (1990). The making of a teacher: Teacher knowledge and teacher education. New York: Teachers College Press

Grossman, P.L., Smagorinsky, P. \& Valencia, S. (1999). Appropriating tools for teaching English: A theoretical framework for research on learning to teach. American Journal of Education, 108 (1), 1-29.

Grossman, P. L., Valencia, S. W., Evans, K., Thompson, C., Martin, S., \& Place, N. (2000). Transitions into teaching: Learning to teach writing in teacher education and beyond. Journal of Literacy Research, 32, 631-662. doi:10.1080/10862960009548098

Grossman, P.L., Valencia, S.W., Thompson, C., Martin, S.D., Place, N., \& Evans, K. (2001). Transitions into teaching: Learning to teach writing in teacher education and beyond. In 
C. Roller (Ed.), Learning to teach reading: Setting the research agenda. Newark, DE: International Reading Association.

Hall, L.A. (2005). Teachers and content area reading: Attitudes, beliefs, and change. Teaching and Teacher Education, 21, 403-414. doi:10.1016/j.tate.2005.01.009

Hammerness, K., Darling-Hammond, L., Grossman, P., \& Shulman, L. (2006). The design of teacher education programs. In L. Darling- Hammond \& J. Bransford (Eds). Preparing Teachers for a Changing World: What Teacher Should Learn and Be Able to Do. (90441). San Francisco, CA.: Jossey Bass.

Hanauer, D. (1997). Student teachers' knowledge of literacy practices in school. Teaching and Teacher Education, 13, 847-862. doi:10.1016/S0742-051X(97)00024-3

Hatch, T. \& Grossman, P. (2009). Learning to look beyond the boundaries of representation: Using technology to examine teaching (Overview for a digital exhibition: Learning from the practice of teaching). Journal of Teacher Education 60, 70-85. doi: $10.1177 / 0022487108328533$

Heller, M.F, Wood, N.J., \& Shawgo, M. (2007). Teaching and learning language arts: From campus to classroom and back again. Journal of Educational Research, 100, 226-234. doi: 10.3200/JOER.100.4.204-210

Hillocks, G. Jr. (2011). Commentary on "Research and secondary English, 1912-2011: Historical continuities and discontinuities in the NCTE imprint." Research in the Teaching of English 46, 187-192.

Houge, T. T., \& Geier, C. (2009). Delivering one-to-one tutoring in literacy via videoconferencing. Journal of Adolescent \& Adult Literacy, 53, 154-163. doi:10.1598/JAAL.53.2.6 
Kane, T. J. \& Cantrell, S. (2010). Learning about teaching: Initial findings from the Measures of Effective Teaching project. Bill \& Melinda Gates Foundation. Retrieved 1/21/10 from http://www.gatesfoundation.org/What-We-Do/US-Program/College-Ready-Education

Kane, T.J. \& Staiger, D.O. (2008). Estimating teacher impacts on student achievement: An experimental evaluation. NBER Working Paper No. 14607. Retrieved from http://www.nber.org/papers/w14607.pdf?new_window=1

Kaufman, J.E. (2004). Language, inquiry, and the heart of learning: Reflection in an English methods course. English Education, 36, 174-191.

Kennedy, M. M. (1999) The role of preservice teacher education. In L. Darling-Hammond. \& G. Sykes (Eds.) Teaching as the Learning Profession: Handbook of Teaching and Policy (54-86). San Francisco: Jossey Bass.

Kinzer, C.K., \& Leander, K. (2003). Technology and the language arts: Implications of an expanded definition of literacy. In J. Flood, D. Lapp, J.R. Squire, \& J.M. Jensen (Eds.), Handbook of research on teaching the English language arts (pp. 546-565). Mahwah, NJ: Lawrence Erlbaum Associates.

Kirkland, D. (2008). "The rose that grew from concrete": Postmodern blackness and new English education. English Journal, 97(5), 69-75.

Kirkland, D. (2010). English(es) in urban contexts: Politics, pluralism, and possibilities. English Education, 42(3), 293-306.

Kober, N. \& Rentner, D.S. (2011). States' progress and challenges in implementing Common Core State Standards. Washington, D.C.: Center on Education Policy.

Kooy, M. (2006). The telling stories of novice teachers: Constructing teacher knowledge in book clubs. Teaching and Teacher Education, 22, 661-674. doi:10.1016/j.tate.2006.03.010 
doi:10.3102/0013189X028004004

Ladson-Billings, G. (1994). The dreamkeepers: Successful teachers of African American children. San Francisco: Jossey-Bass.

Lai, G., \& Calandra, B. (2010). Examining the effects of computer-based scaffolds on novice teachers' reflective journal writing. Educational Technology Research \& Development, 58, 421-437. doi: 10.1007/s11423-009-9112-2

Lee, J. and Young, C. (2010). Building wikis and blogs: Pre-service teacher experiences with web-based collaborative technologies in an interdisciplinary methods course. Then Journal, 287. Retrieved from http: http://thenjournal.org/feature/287/

Lesley, M., Watson, P., \& Elliott, S. (2007). "School” reading and multiple texts: Examining the metacognitive development of secondary-level preservice teachers. Journal of Adolescent \& Adult Literacy, 51(2), 150-162. doi:10.1598/JAAL.51.2.6

Lester, J.H. (2000). Secondary instruction: Does literacy fit in? High School Journal, 83(3), 1016.

Lortie, D. C. (1975/2002). Schoolteacher. Chicago: University of Chicago Press.

Lucas, T., Villegas, A.M. \& Freedman-Gonzalez, M. (2008). Linguistically responsive teacher education: Preparing classroom teachers to teach English language learners. Journal of Teacher Education, 59, 361-373.

Luce-Kapler, R. \& Dobson, T. (2005). In search of a story: Reading and writing e-literature. Reading Online, 8(6). Retrieved from: http://www.readingonline.org/articles/luce-kapler/ Margerison, P.S. (1995). Changing hearts, Changing minds: Encouraging student teachers to use multicultural literature. English Education, 27, 258-267.

Marshall, J. \& Smith, J (1997). Teaching as we're taught: The university's role in the education 
of English teachers. English Education, 29, 246-270.

Matthew, K. I., Felvegi, E., \& Callaway, R. A. (2009). Wiki as a collaborative learning tool in a language arts methods class. Journal of Research on Technology in Education, 42(1), 51-72.

McCallister, C. (2002). Learning to let them learn: Yielding power to students in a literacy methods course. English Education, 34, 281-301.

McCann, Thomas M., Johannessen, Larry R., and Bernard Ricca. (2005). Responding to new teachers' concerns. Educational Leadership, 62(8), 30-34.

McCracken, N. (2004). Surviving shock and awe: NCLB vs. colleges of education. English Education, 36, 104-118.

McVee, M. B., Bailey, N. M., \& Shanahan, L. E. (2008). Teachers and teacher educators learning from new literacies and new technologies. Teaching Education, 19(3), 197-210. doi: $10.1080 / 10476210802250216$

Merkley, D., Schmidt, D., \& Allen, G. (2001). Addressing the English language arts technology standard in a secondary reading methodology course. Journal of Adolescent and Adult Literary, 45, 220-231.

Miller, sj. (2008). "Speaking" the walk, "Speaking" the talk: Embodying critical pedagogy to teach young adult literature. English Education, 40, 145-154.

Miller, S.M. (2007). English teacher learning for new times: Digital video composing as multimodal literacy practice. English Education, 40(1), 61-83.

Moje, E. (2008). Foregrounding the disciplines in secondary literacy teaching and learning: A call for change. Journal of Adolescent \& Adult Literacy, 52, 96-107.

Moll, L.C., Amanti, C., Neff, D., \& Gonzalez, N. (1992). Funds of knowledge for teaching: 
Using a qualitative approach to connect homes and classrooms. Theory into Practice, 31 , 132-141.

Moore, D., Bean, T.W., Birdyshaw, D., \& Rycik, J. (1999). Adolescent literacy: A position statement. Journal of Adolescent \& Adult Literacy, 43, 97-112.

Morrell, E. (2004). Becoming critical researchers: Literacy and empowerment for urban youth. New York: Peter Lang.

NCTE (National Council of Teachers of English). (n.d.) Positions statements on literacy. Retrieved from http://www.ncte.org/positions/literacy

NCTE. (n.d.). Position statements on reading. Retrieved from http://www.ncte.org/positions/reading

NCTE. (2006). Position paper on the role of English teachers in educating English language learners. Retrieved from http://www.ncte.org/positions/statements/teacherseducatingell

NCTE. (2012). Standard for preparation of teachers of secondary English language arts 7-12: April 2012. Retrieved from http://www.ncte.org/library/NCTEFiles/Groups/CEE/NCATE/NCTE\%20RevisedStandar ds\%204\%2010\%2012.pdf

NCATE. (2008). Unit standards in effect 2008. Retrieved 1/22/2011 from http://www.ncate.org/Standards/NCATEUnitStandards/UnitStandardsinEffect2008/tabid/ $\underline{476 / \text { Default.aspx }}$

NETS (National Education Technology Standards) for Students. International Society for Technology Education. Retrieved from: http://www.iste.org/standards/nets-for-students NETS (National Education Technology Standards) for Teachers. International Society for Technology Education. Retrieved from: http://www.iste.org/standards/nets-for-teachers 
Newell, G. \& Connors, S. (2011). "Why do you think that?" A supervisor's Mediation of a preservice English teacher's understanding of instructional scaffolding. English Education, April 2011.

Newell, G.E., Gingrich, R.S. \& Johnson A.B. (2001) Considering the contexts for appropriating theoretical and practical tools for teaching middle and secondary English. Research in the Teaching of English, 35(2), 302-43.

Newell, G. E., Tallman, L., \& Letcher, M. (2009). A longitudinal study of consequential transitions in the teaching of literature. Research in the Teaching of English 44, 89-126.

Nieto, S. (2003). Professional multicultural questions. Educational Leadership, 60, 6-10.

Nieto, S. (2009). From surviving to thriving. Educational Leadership, 66(5), 8-13.

Nystrand, M., with Gamoran, A., Kachur, R. \& Prendergast, C. (1997). Opening dialogue: Understanding the dynamics of language and learning in the English classroom. New York: Teachers College Press.

O’Donnell-Allen, Cindy. (2001). Teaching with a questioning mind: The development of a teacher research group into a discourse community. Research in the Teaching of English. 36. $161-211$.

Olson, C.B. \& Land, R. (2007). A cognitive strategies approach to reading and writing instruction for English language learners in secondary school. Research in the Teaching of English, 41(3), 269-303.

Pease-Alvarez, L. \& Samway, K. D. (2008). Negotiating a top-down reading program mandate: The experiences of one school. Language Arts, 86 (1), 32-41.

Perry, T., \& Delpit, L. (1998). The real Ebonics debate: Power, language, and the education of African-American children. Boston: Beacon Press. 
Pope, C.A. (1999). Reflection and refraction: A reflexive look at an evolving model for methods instruction. English Education, 31, 177-200.

Pope, C., \& Golub, J. (2000). Preparing tomorrow's English language arts teachers today: Principles and practices for infusing technology. Contemporary Issues in Technology and Teacher Education [Online serial], 1 (1). Retrieved from: http://www.citejournal.org/vol1/iss1/currentissues/english/article1.htm

Portes, P. R. \& Smagorinsky, P. (2010). Static structures, changing demographics: Educating teachers for shifting populations in stable schools. English Education, 42, 236-247.

Richmond, K.J. \& Whyte, A. (2004). Questioning our methods: Report on the Commission on English Methods Teaching and Learning. English Education, 36, 324-328.

Rosen, L.M. \& Abt-Perkins, D. (2000). Preparing English teachers to teach diverse populations: Beliefs, challenges, and proposals for change. English Education, 32, 251-266.

Rosen, C \& Gere, A. R. (1996). Both sides of the desk: Collaborative self-study in teacher education. Action in Teacher Education, 18 56-67.

Rubinstein-Avila, E. (2003). Facing reality: English language learners in middle school classes English Education, 35, 122-136.

Ryan, J. \& Scott, A. (2008). Integrating technology into teacher education: How online discussion can be used to develop informed and critical literacy teachers. Teaching and Teacher Education, 24(6), 1635-1644.

Rymes, B. (2003). Eliciting narratives: Drawing attention to the margins of classroom talk. Research in the Teaching of English, 37(3), 380-407.

Seo, K.K., Templeton, R., \& Pellegrino, D. (2008). Creating a ripple effect: Incorporating 
multimedia-assisted project-based learning in teacher education. Theory Into Practice, 47, 259-265. doi: 10.1080/00405840802154062

Scherff, L. \& Hahs-Vaughan, D. L. (2008). What we know about English language arts teachers: An analysis of the 1999-2000 SASS and 2000-2001 TFS databases. English Education, 40, 174-200.

Scherff, L. \& Piazza, C. (2005). The more things change, the more they stay the same: A survey of high school students' writing experiences. Research in the Teaching of English, 39 (3), 271-304.

Sherry, M.B. \& Tremmel, R. (2012). English Education 2.0: An analysis of websites that contain videos of English teaching. English Education, 45(1), 35-70.

Shulman, L. S. (1987). Knowledge and teaching: Foundations of the new reform. Harvard Educational Review, 57, 1-22.

Skerrett, A. (2010). Of literary import: A case of cross-national similarities in the secondary English curriculum in the United States and Canada. Research in the Teaching of English. 45(1), 36-58.

Sleeter, C. (2001). Preparing teachers for culturally diverse schools: Research and the overwhelming presence of Whiteness. Journal of Teacher Education, 52, 94-106.

Slick, S. K. (1998). A University supervisor negotiates territory and status. Journal of Teacher Education, vol. 49: pp. 306-315.

Smagorinsky, P. (1999). Time to teach. English Education, 32(1), 50-73.

Smagorinsky, P. (2010). The culture of learning to teach: The self-perpetuating cycle of conservative schooling. Teacher Education Quarterly 37 (2), 19-31.

Smagorinsky, P., Jakubiak, C., \& Moore, C. (2008). Student teaching in the contact zone: 
Learning to teach amid multiple interests in a vocational English class. Journal of Teacher Education, 59, 442-454. DOI: 10.1177/0022487108324329.

Smagorinsky, P., Lakly, A., \& Johnson, T. S. (2002). Acquiescence, accommodation, and resistance in learning to teach within a prescribed curriculum. English Education, 34, 187-213.

Smagorinsky, P. \& Whiting, M. E. (1995). How English teachers get taught: Methods of teaching the methods class. Urbana, IL: NCTE.

Smagorinsky, P, Wilson, A.A., \& Moore, C. (2011). Teaching grammar and writing: A beginning teacher's dilemma. English Education, 43, 262-292.

Smagorinsky, P., Rhym, D., \& Moore, C. (2013). Competing centers of gravity: A beginning English teacher's socialization process within conflictual settings. English Education, 45(2), 147-183.

Smith, E.R. \& Anagnostopoulos, D. (2008). Developing pedagogical content knowledge for literature-based discussions in a cross-institutional network. English Education, 41, 3965.

Smitherman, G. (1999). Talking that talk: Language, culture, and education in African America. New York: Routledge.

Spalding, E., Wang, J., Lin, E., \& Hu, G. (2009). Analyzing voice in the writing of Chinese teachers of English. Research in the Teaching of English. 44(1), 23-51.

Stockinger, P. C. (2007). Living in, learning from, looking back, breaking through in the English language arts methods course: A case study of two preservice teachers. English Education, 39, 201-225.

Stotsky, S. (2005) The state of state English standards. Washington, D.C.: Thomas B. Fordham 
Foundation.

Swenson, J., Rozema, R., Young, C. A., McGrail, E., \& Whitin, P. (2005). Beliefs about technology and the preparation of English teachers: Beginning the conversation. Contemporary Issues in Technology and Teacher Education [Online serial], 5(3/4). Retrieved from http://www.citejournal.org/vol5/iss3/languagearts/article1.cfm

Swenson, J., Young, C.A., McGrail, E., Rozema, R. \& Whitin, P. (2006). Extending the conversation: New technologies, new literacies, and English education. English Education, 38, 351-369.

Tendero, A. (2006). Facing versions of the self: The effects of digital storytelling on English education. Contemporary Issues in Technology and Teacher Education, 6(2), 174-194. Retrieved from http://www.citejournal.org/vol6/iss2/languagearts/article2.cfm

Thieman, G.Y. (2008). Using technology as a tool for learning and developing $21^{\text {st }}$ century citizenship skills: An examination of the NETS and technology use by preservice teachers with their K-12 students. Contemporary Issues in Technology and Teacher Education, 8(4). Retrieved from http://www.citejournal.org/vol8/iss4/socialstudies/article1.cfm

Tremmel, R. (2010). On the horns of a dilemma: Deweyan progressivism and English teacher education. English Education, 42, 121-147.

United States Census Bureau. (2010). American fact finder. Retrieved August 10, 2012, from http://factfinder2.census.gov/faces/nav/jsf/pages/index.xhtml

United States Department of Education (USDOE). (2012). Title II state report 2011. Retrieved from https://title2.ed.gov/Title2STRC/ChooseState.aspx?Type=Map\&Year=2011

Villanueva, V. (1993). Bootstraps: From an American academic of color. Urbana, IL: NCTE. 
Villegas, A. \& Lucas, T. (2002). Educating Culturally Responsive Teachers: A Coherent Approach. NY: State University of NY Press.

Wall, S.V. (2004). Writing the "self" in teacher research: The potential powers of a new professional discourse. English Education, 36(4), 289-317.

Wilson, A. A. (2011). A social semiotics framework for conceptualizing content area literacies. Journal of Adolescent \& Adult Literacy, 54, 435-444. doi:10.1598/JAAL.54.6.5

Wilson, N., Grisham, D., \& Smetana, L. (2009). Investigating content area teachers' understanding of a content literacy framework: A yearlong professional development initiative. Journal of Adolescent \& Adult Literacy, 52(8), 708-718. doi:10.1598/JAAL.52.8.6

Wilson, S.M., Floden, R.E., Ferrini-Mundy, J. (2002). Teacher preparation research: An insider's view from the outside. Journal of Teacher Education, 53, 190-204. doi:10.1177/0022487102053003002

Wolfe, P. (2010). Preservice teachers planning for critical literacy teaching. English Education, 42, 368-390.

Yagelski, R. (2005). Computers, literacy and being: Teaching with technology for a sustainable future. Retrieved August 5, 2006, from the State University of New York at Albany Web site: http://www.albany.edu/faculty/rpy95/webtext/

Yoon, B. (2007). Offering or limiting opportunities: Teachers' roles and approaches to Englishlanguage learners' participation in literacy activities. The Reading Teacher, 61, 216-225.

Young, C. A., \& Bush, J. (2004). Teaching the English language arts with technology: A critical approach and pedagogical framework. Contemporary Issues in Technology and Teacher Education [Online serial], 4(1). Retrieved from 
http://www.citejournal.org/vol4/iss1/languagearts/article1.cfm

Zeichner, K. (2010). Rethinking the connections between campus courses and field experiences in college- and university-based teacher education. Journal of Teacher Education, 61, 8999. doi:10.1177/0022487109347671

Zigo, D., \& Derrico, R. D. (2009). Co-learning agreements in research and teaching: Another approach to collaboration in teacher education. English Education, 41, 135-157. 
Table 1. Articles recovered from major journals on English teacher preparation, post-1995

\begin{tabular}{|c|c|c|c|c|c|c|}
\hline Journal & Search & Relevant & Search & Relevant & Search & Relevant \\
\hline name & "English & research & "English & research & "Methods & research \\
\hline & education" & articles & teacher & articles & Course" & articles \\
\hline
\end{tabular}

\begin{tabular}{lllllll}
\hline Research & 87 & 6 & 3 & 2 & 4 & 3 \\
in the & & & & & \\
Teaching & & & & & \\
of English & & 26 & 22 & 5 & 28 & 11 \\
English & 266 & 26 & & &
\end{tabular}

\section{Education}

$\begin{array}{lllllll}\text { Journal of } & 40 & 12 & 1 & 1 & 81 & 8 \\ \text { Teacher } & & & & & \\ \text { Education } & & & & & & \\ \text { Teaching } & 29 & 6 & 0 & 0 & 196 & \end{array}$

\section{Teacher}

\section{Education}

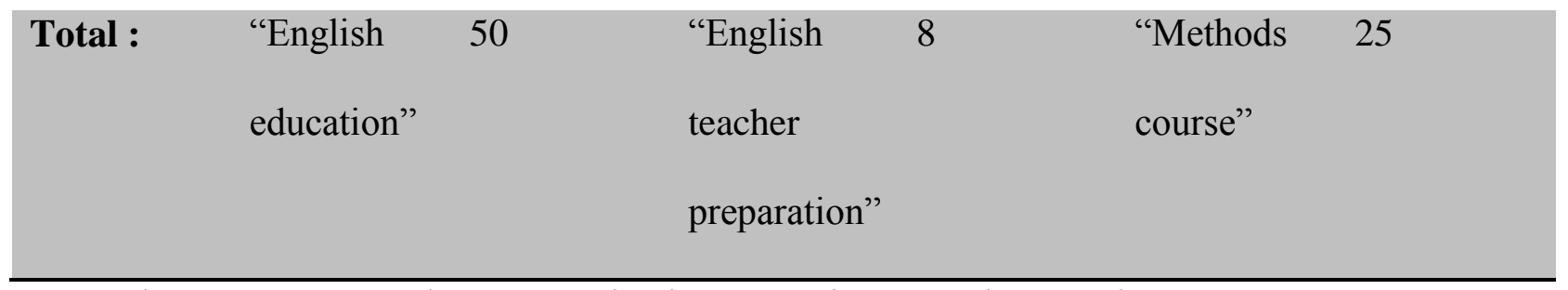

Note: there is minor overlap among the three searches in each journal. 
Table 2: Research articles reviewed in each of the subcategories for this article.

Preparing to Integrating Preparing for Preparing for Integrating teach literacy field work with linguistic technology skills experiences standards and diversity and into teaching with methods high-stakes English and learning assessments language experiences learners

\begin{tabular}{llllll}
\hline $\begin{array}{l}\text { Number of } \\
\text { articles } \\
\text { reviewed }\end{array}$ & 17 & 11 & 1 & 4 & 17 \\
\hline
\end{tabular}

